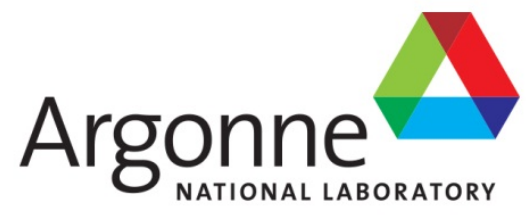

\title{
A Groundwater Model to Assess Water Resource Impacts at the Riverside East Solar Energy Zone
}

Environmental Science Division 
About Argonne National Laboratory

Argonne is a U.S. Department of Energy laboratory managed by UChicago Argonne, LLC under contract DE-AC02-06CH11357. The Laboratory's main facility is outside Chicago,

at 9700 South Cass Avenue, Argonne, Illinois 60439. For information about Argonne

and its pioneering science and technology programs, see www.anl.gov.

\section{Availability of This Report}

This report is available, at no cost, at http://www.osti.gov/bridge. It is also available

on paper to the U.S. Department of Energy and its contractors, for a processing fee, from:

U.S. Department of Energy

Office of Scientific and Technical Information

P.O. Box 62

Oak Ridge, TN 37831-0062

phone (865) 576-8401

fax (865) 576-5728

reports@adonis.osti.gov

\section{Disclaimer}

This report was prepared as an account of work sponsored by an agency of the United States Government. Neither the United States Government nor any agency thereof, nor UChicago Argonne, LLC, nor any of their employees or officers, makes any warranty, express or implied, or assumes any legal liability or responsibility for the accuracy, completeness, or usefulness of any information, apparatus, product, or process disclosed, or represents that its use would not infringe privately owned rights. Reference herein to any specific commercial product, process, or service by trade name, trademark, manufacturer, or otherwise, does not necessarily constitute or imply its endorsement, recommendation, or favoring by the United States Government or any agency thereof. The views and opinions of document authors expressed herein do not necessarily state or reflect those of the United States Government or any agency thereof, Argonne National Laboratory, or UChicago Argonne, LLC. 


\section{A Groundwater Model to Assess Water Resource Impacts at the Riverside East Solar Energy Zone}

by

Chris B. Greer, ${ }^{*}$ John J. Quinn, Adrianne E. Carr, and Ben L. O'Connor

Environmental Science Division, Argonne National Laboratory

${ }^{*}$ Currently at Fermilab, Batavia, Illinois

prepared for

Bureau of Land Management

National Renewable Energy Coordination Office

U.S. Department of the Interior

Washington, D.C.

December 2013 
This page intentionally left blank. 


\section{CONTENTS}

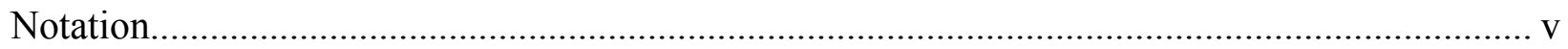

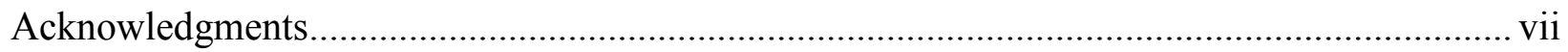

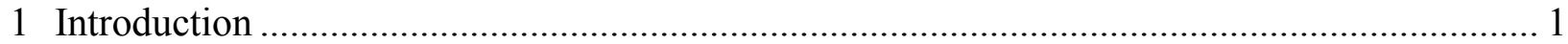

1.1 Bureau of Land Management's Solar Energy Program ................................................ 2

1.2 Riverside East Solar Energy Zone ....................................................................... 2

2 Hydrogeologic Setting and Model Input Parameters ..................................................... 5

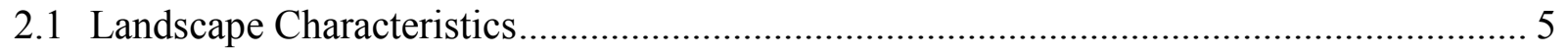

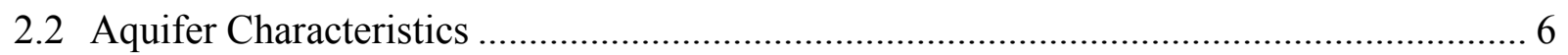

2.3 Hydraulic Conductivity of the Alluvial Fill .............................................................. 7

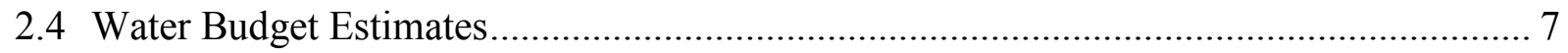

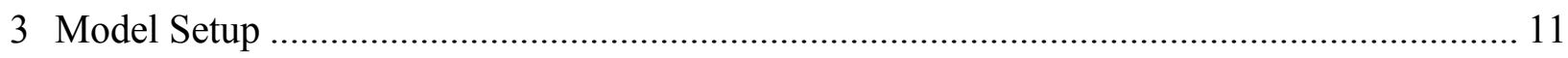

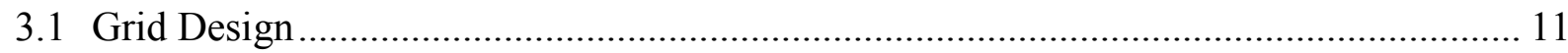

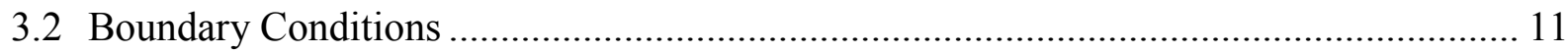

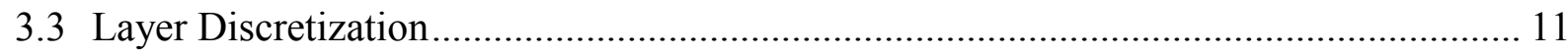

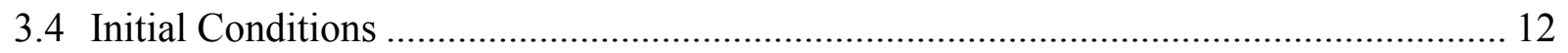

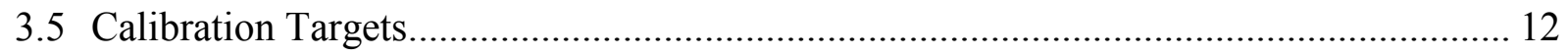

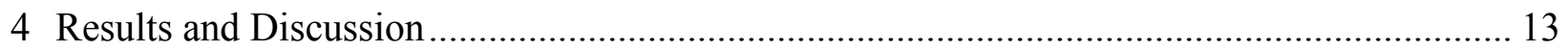

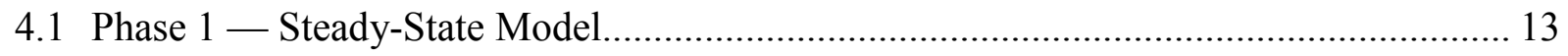

4.2 Phase 2 - Transient Model................................................................................ 13

4.3 Phase 3 - Transient Model with Solar Development................................................. 19

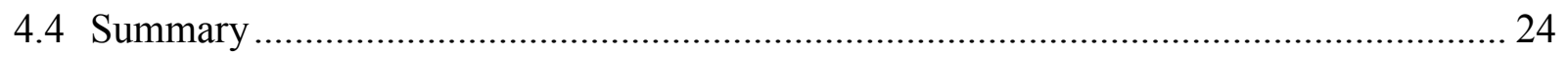

4.5 Implications for Future Model Development ............................................................ 25

4.6 Summary of Riverside East SEZ Model Files and Future Use.................................... 26

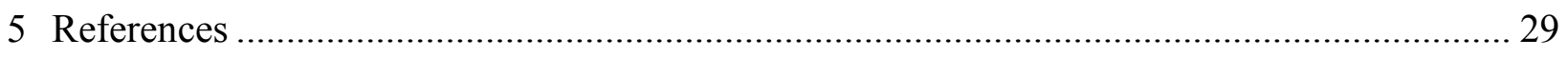

\section{TABLES}

1 Estimates of Selected Components of Riverside East SEZ Model Inflows and Outflows....... 8

2 Comparison of Selected Variables from Groundwater Flow Models Developed across the Riverside East SEZ ..... 


\section{FIGURES}

1 Riverside East SEZ That Spans the Chuckwalla Valley, Palo Verde Mesa, and Palo Verde Valley Groundwater Basins in Southern California ............................................ 3

2 Riverside East Area Surface Elevations and Numerical Model Grid Features ......................... 5

3 Interpolated Bedrock Elevation Contours Used as the Bottom Surface of the Model .............. 6

4 (a) Calibrated Pre-1942 Steady-State Head Contours and (b) Computed Versus Observed Heads at Observation Points for the Pre-1942 Steady-State Model ......................... 14

5 Distribution of Hydraulic Conductivity from the Calibration of the Transient 1942-2010 Model Using PEST

6 (a) Transient Model Estimated Heads after 69 Years of Agricultural, Mining, and Municipal Pumping between 1942 and 2010; (b) Calibration Results for the Final Time Step of the Phase 2 Model.

7 Relative Sensitivities of the Transient Model to (a) Hydraulic Conductivity and (b) Recharge at Pilot Points Used in the PEST Calibration Process

8 Calculated Heads after 20 Years of SEZ Pumping Considering the High-Water-Demand Scenario in Addition to Withdrawals for Agricultural, Mining, and Municipal Uses............ 21

9 Additional Drawdown Due to a Simulated 20 Years of SEZ Pumping Considering the High-Water-Demand Scenario

10 Additional Drawdown Due to a Simulated 20 Years of SEZ Pumping Considering the Medium-Water-Demand Scenario

11 Additional Drawdown Due to a Simulated 20 Years of SEZ Pumping Considering the Low-Water-Demand Scenario

12 USGS NWIS Data for the Midland Well and Surrounding Wells in the Palo Verde Mesa and Rice Valley Groundwater Basins 


\section{NOTATION}

The following is a list of acronym, initials, symbols, and abbreviations (including units of measure) used in this document.

\section{Acronyms, Initials, Symbols and Abbreviations}

$\begin{array}{ll}\text { BLM } & \text { Bureau of Land Management } \\ \text { CAP } & \text { Central Arizona Project } \\ \text { CDWR } & \text { California Department of Water Resources } \\ \text { CHD } & \text { constant-head boundary/time-variant specified head package in MODFLOW } \\ \text { CRA } & \text { Colorado River Aqueduct } \\ \text { DEM } & \text { Digital Elevation Model } \\ \text { DOE } & \text { U.S. Department of Energy } \\ \text { DRN } & \text { drain package in MODFLOW } \\ \text { GIS } & \text { geographic information system } \\ \text { GMS } & \text { Groundwater Modeling System } \\ \text { K } & \text { hydraulic conductivity } \\ \text { PEIS } & \text { programmatic environmental impact statement } \\ \text { PEST } & \text { Parameter Estimation Tool } \\ \text { PVID } & \text { Palo Verde Irrigation District } \\ \text { RIV } & \text { river package in MODFLOW } \\ \text { SEZ } & \text { Solar Energy Zone } \\ \text { USGS } & \text { U.S. Geological Survey }\end{array}$

\section{Units of Measure}

$\begin{array}{ll}\text { ac-ft } & \text { acre-foot (feet) } \\ \mathrm{d} & \text { day(s) } \\ \mathrm{ft} & \text { foot (feet) } \\ \mathrm{ft}^{2} & \text { square foot (feet) } \\ \mathrm{GW} & \text { gigawatt(s) } \\ \mathrm{in} . & \text { inch(es) } \\ \mathrm{km} & \text { kilometer(s) } \\ \mathrm{km}^{2} & \text { square kilometer(s) } \\ \mathrm{m} & \text { meter(s) } \\ \mathrm{m}^{2} & \text { square meter(s) } \\ \mathrm{m}^{3} & \text { cubic meter(s) } \\ \mathrm{mi} & \text { mile(s) } \\ \mathrm{yr} & \text { year(s) }\end{array}$

Elevations are reported relative to mean sea level using the NAVD88 vertical datum. 
This page intentionally left blank. 


\section{ACKNOWLEDGMENTS}

We thank Peter Godfrey and Noel Ludwig of the Bureau of Land Management (BLM) for providing guidance and direction on and data for developing the water balance for the Riverside East SEZ Model and for discussing water resources for solar projects under construction. We would also like to thank Larisa Ford, Lee Koss, Paul Summers, and Ray Brady of the BLM for providing guidance and oversight for the groundwater modeling project associated with BLM's Solar Energy Program. Colin Booth of Northern Illinois University provided a technical review of the model document. The work was funded by the BLM's National Renewable Energy Coordination Office under interagency agreement through U.S. Department of Energy Contract DE-AC02-06CH11357. 
This page intentionally left blank. 


\title{
A GROUNDWATER MODEL TO ASSESS WATER RESOURCE IMPACTS AT THE RIVERSIDE EAST SOLAR ENERGY ZONE
}

\author{
by \\ C.B. Greer, J.J. Quinn, A.E. Carr, and B.L. O'Connor \\ Environmental Science Division \\ Argonne National Laboratory
}

\section{INTRODUCTION}

This study discusses the development of a groundwater flow model to use in examining the influence of potential groundwater withdrawal on the nearby environment. The groundwater withdrawal would be to support utility-scale solar energy development at the Riverside East Solar Energy Zone (SEZ) as a part of the Bureau of Land Management's (BLM's) solar energy program. The Riverside East SEZ groundwater model (referred to as the Riverside East SEZ Model, or the model) is a numerical model that was developed by using established software and hydrogeological principles and that relies on publicly available geospatial, geologic, and hydrologic data. Although the model focuses on the simulated drawdown effects of groundwater withdrawals, its construction is based on a detailed hydraulic "head" modeling approach, with true elevation control to provide a platform for more in-depth modeling analyses. Because the basin hydrostratigraphy has been simplified into one layer, the model is intended to be used by water managers and others only as a general indicator of groundwater elevations and potential drawdown. The model was developed in three phases:

1. Calibration to steady-state, pre-1942 conditions (before the Colorado River Aqueduct began operations in 1942) to establish starting heads for the subsequent transient modeling;

2. Automated calibration of a transient model to assess the use of mining, municipal, and agricultural water from 1942 through 2010 (before the first solar facility began groundwater withdrawal related to construction in 2011); and

3. Development of a set of transient model scenarios in simulations to assess the simulated impact of 20 years of groundwater withdrawals for various development scenarios of the Riverside East SEZ.

This report describes the development of the Riverside East SEZ Model and summarizes the results from simulating the impacts from a full build-out of the Riverside East SEZ, considering three water-demand categories (high, medium, and low) based on technology-specific parameters. This report also suggests some approaches for improving the model as geologic and hydrologic data from individual project investigations associated with the siting, construction, and operation of utility-scale solar energy facilities become available. 


\subsection{Bureau of Land Management's Solar Energy Program}

In 2012, the BLM officially established its Solar Energy Program, which facilitates permitting of utility-scale solar energy development on BLM lands in six southwestern states (Arizona, California, Colorado, Nevada, New Mexico, and Utah) in an environmentally responsible manner (BLM 2012). As a part of the Solar Energy Program, BLM established SEZs. The BLM, together with the U.S. Department of Energy (DOE), analyzed the potential environmental impacts of the Solar Energy Program in the Final Programmatic Environmental Impact Statement for Solar Energy Development in Six Southwestern States (Solar PEIS), including impacts on water resources (BLM and DOE 2012). Groundwater is the primary water resource available for solar energy development in most of the SEZs, and impacts of groundwater withdrawals were investigated qualitatively and semi-quantitatively in the Solar PEIS to assess the range of potential effects. The impacts of reduced groundwater flow to streams, springs, seeps, and wetlands would depend on the connectivity of surface water and groundwater in the region. These impacts would include a decreased supply of water for downstream users; loss of wetland vegetation species; loss of habitat and forage for wildlife, wild horses, and livestock; and others.

As a part of the Solar PEIS analysis, water requirements for cooling and/or washing at solar energy facilities were examined for different technologies and varying levels of development and compared with basin-scale water budgets. In addition, one-dimensional groundwater modeling was performed to examine potential radial drawdown for different solar development scenarios. As a follow-on to the work done for the Solar PEIS, BLM identified seven SEZs, including the Riverside East SEZ, for which three-dimensional groundwater models would be developed. The models are being used to examine potential groundwater impacts associated with the proposed development of the SEZs; the focus is on examining groundwater drawdown and potential loss of connectivity to surface water features, springs, and vegetation. In addition to these analyses, the developed numerical groundwater models are being made available through the Solar PEIS web site so that they can be used for project-scale review and for the development of long-term monitoring programs.

\subsection{Riverside East Solar Energy Zone}

The Riverside East SEZ covers approximately 150,000 acres $\left(607 \mathrm{~km}^{2}\right)$ and is located along an east-west corridor that contains a stretch of I-10 extending between the towns of Desert Center and Blythe in southern California (Figure 1). Several utility-scale solar energy projects are under construction or proposed within this SEZ, which has a full build-out capacity of 13 to $24 \mathrm{GW}$ based on assumptions stated in the Solar PEIS (BLM and DOE 2010, 2012). Five large transmission lines, plus one more that is under construction, pass through the SEZ, primarily in its southeastern and western portions (BLM and DOE 2010).

The Riverside East SEZ is within the Chuckwalla Valley and Palo Verde Mesa groundwater basins (Figure 1). These arid, alluvial basins are bounded by bedrock mountains, characteristic of the basin and range physiographic province. The SEZ has surface elevations ranging between 450 and $1,000 \mathrm{ft}(137$ and $305 \mathrm{~m})$, and its general drainage pattern is from the northwest to the 


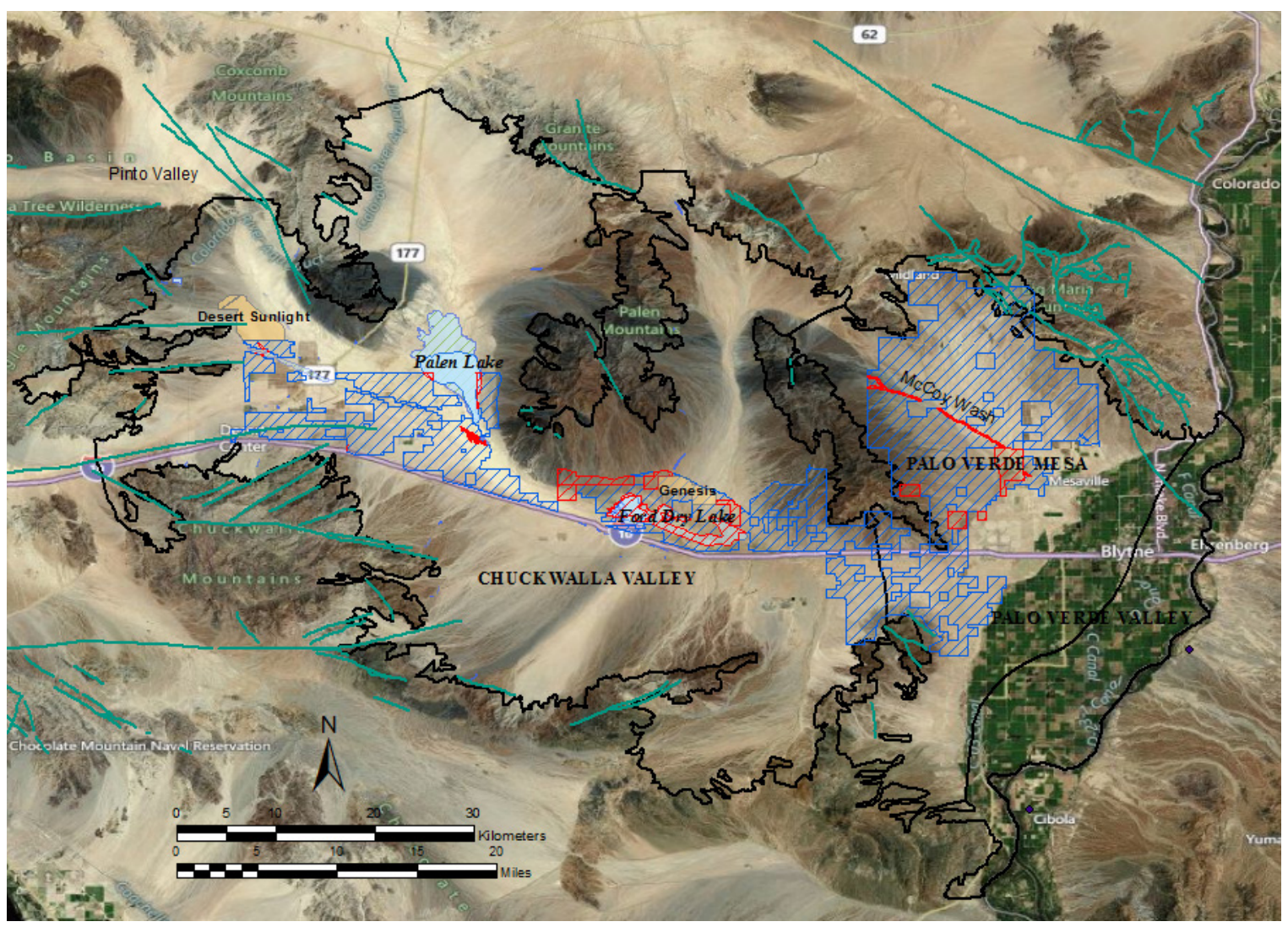

Figure 1 Riverside East SEZ That Spans the Chuckwalla Valley, Palo Verde Mesa, and Palo Verde Valley Groundwater Basins in Southern California (mapped geologic faults are in teal, SEZ development areas are in blue hatching, SEZ nondevelopment areas are in red hatching, groundwater basins are outlined in black)

southeast toward the Colorado River, which flows through the Palo Verde Valley basin to the east (Figure 1). The Colorado River and Palo Verde Irrigation District drainage ditches are within the Colorado River floodplain and serve as the primary groundwater discharge areas for the modeled region.

The primary consideration for groundwater management at the Riverside East SEZ relates to managing the allocations of water from the Colorado River, which is managed by an assemblage of compacts, federal laws, court decrees, and contracts that comprise the "Law of the River." The Colorado River "Accounting Surface" method was developed by the U.S. Geological Survey (USGS), in accordance with the Law of the River, to determine static groundwater elevations in contributing basins that replenish the Colorado River. The Chuckwalla Valley and Palo Verde Mesa groundwater basins are considered to be contributing basins (Wilson and Owen-Joyce 1994; Weile et al. 2008). The Accounting Surface elevation is between 238 and $240 \mathrm{ft}$ (72.5 and $73 \mathrm{~m})$ in the Chuckwalla Valley, and it is between approximately $218 \mathrm{ft}(66 \mathrm{~m})$ and more than $270 \mathrm{ft}(82 \mathrm{~m}$ ) in the Palo Verde Mesa area (Weile et al. 2008). From west to east across the Chuckwalla Valley and into the Palo Verde Mesa, recently measured groundwater elevations are approximately $488 \mathrm{ft}(149 \mathrm{~m})$ near Desert Center, $288 \mathrm{ft}(88 \mathrm{~m})$ near Palen Lake, and $245 \mathrm{ft}$ $(75 \mathrm{~m})$ near the split between the two groundwater basins (USGS 2012). 
The groundwater management implications of the Colorado River Accounting Surface elevations are beyond the scope of this study. In general, if groundwater elevations go below the Accounting Surface elevation, then subsequent groundwater withdrawals are considered Colorado River extractions and infringe on water rights established in the Law of the River. This interpretation does not necessarily represent the true physical nature of surface watergroundwater connectivity for the Colorado River, but it does allow for a basin-wide assessment of potential effects on Colorado River flows that are critical in supplying water users. 


\section{HYDROGEOLOGIC SETTING AND MODEL INPUT PARAMETERS}

\subsection{Landscape Characteristics}

The Riverside East SEZ Model covers an aerial extent of the alluvial plain regions of the Chuckwalla Valley and Palo Verde Mesa groundwater basins. Ground surface elevations across the alluvial plain represented in the model range from about $1,942 \mathrm{ft}(592 \mathrm{~m})$ at the mountainfront intersection with the alluvial fan edge in the western Chuckwalla Valley to about $220 \mathrm{ft}$ $(67 \mathrm{~m})$ at the downstream end of the Colorado River floodplain in the southeast (Figure 2). There is a change in elevation of up to $130 \mathrm{ft}(40 \mathrm{~m})$ along the mesa that divides the Palo Verde Mesa basin from the Palo Verde Valley basin (Colorado River floodplain). The Chuckwalla Valley basin receives ephemeral surface flow from Pinto Valley in the northwest but is a closed basin with surface drainage terminating in playa lakes (Palen Lake and Ford Dry Lake) in the central portions of the valley. The Palo Verde Mesa basin drains eastward toward the Colorado River

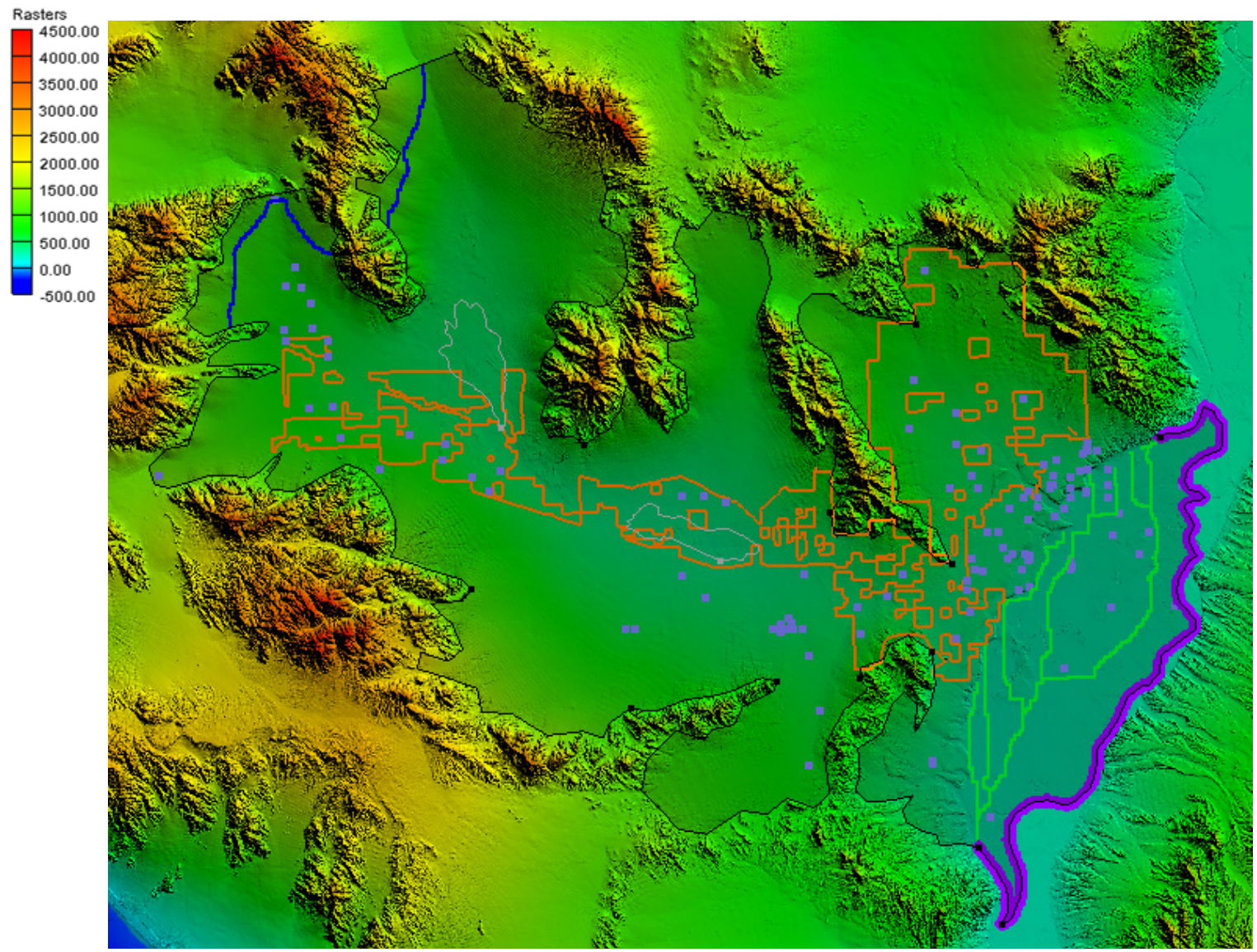

Figure 2 Riverside East Area Surface Elevations (in ft) and Numerical Model Grid Features (model grid is outlined in black, SEZ is outlined in red, present-day wells are represented by purple squares, irrigation canals are represented by drain cells [green line], the Colorado River is represented as a series of constant-head cells on the eastern edge of the model [purple line], and the Colorado River Aqueduct is represented by river cells [blue line] near the northwestern edges of the model) 
floodplain by numerous ephemeral streams, primarily McCoy Wash in its northern portion. Segments of the Colorado River Aqueduct run through the western edges of the Chuckwalla Valley basin (Figures 1 and 2). The Kaiser mining area is near the Pinto Valley on the western edge of the Chuckwalla Valley, and scattered agricultural areas are located throughout the basins.

\subsection{Aquifer Characteristics}

The maximum thickness of the alluvial sediments in the basins, estimated from borehole logs, ranges from approximately $700 \mathrm{ft}(213 \mathrm{~m})$ to more than 1,200 ft (366 m) (Metzger et al. 1973; CDWR 1979). However, WorleyParsons (2009) presented an analysis of previously obtained USGS Bouger residual gravity data (see Mariano et al. 1986) that suggested greater depths to bedrock in some parts of the basins, up to over $1 \mathrm{mi}(1.6 \mathrm{~km})($ e.g., in the pronounced local elevation low in the center of Chuckwalla Valley). For this study, the relationships among the gravity modeling results, the residual gravity data, and the observed elevations of the bedrock surface from borehole logs were all used to estimate the elevation of the bedrock surface across the three modeled groundwater basins (Figure 3). The estimated and observed bedrock elevations were used to define the lower boundary of this groundwater flow model.

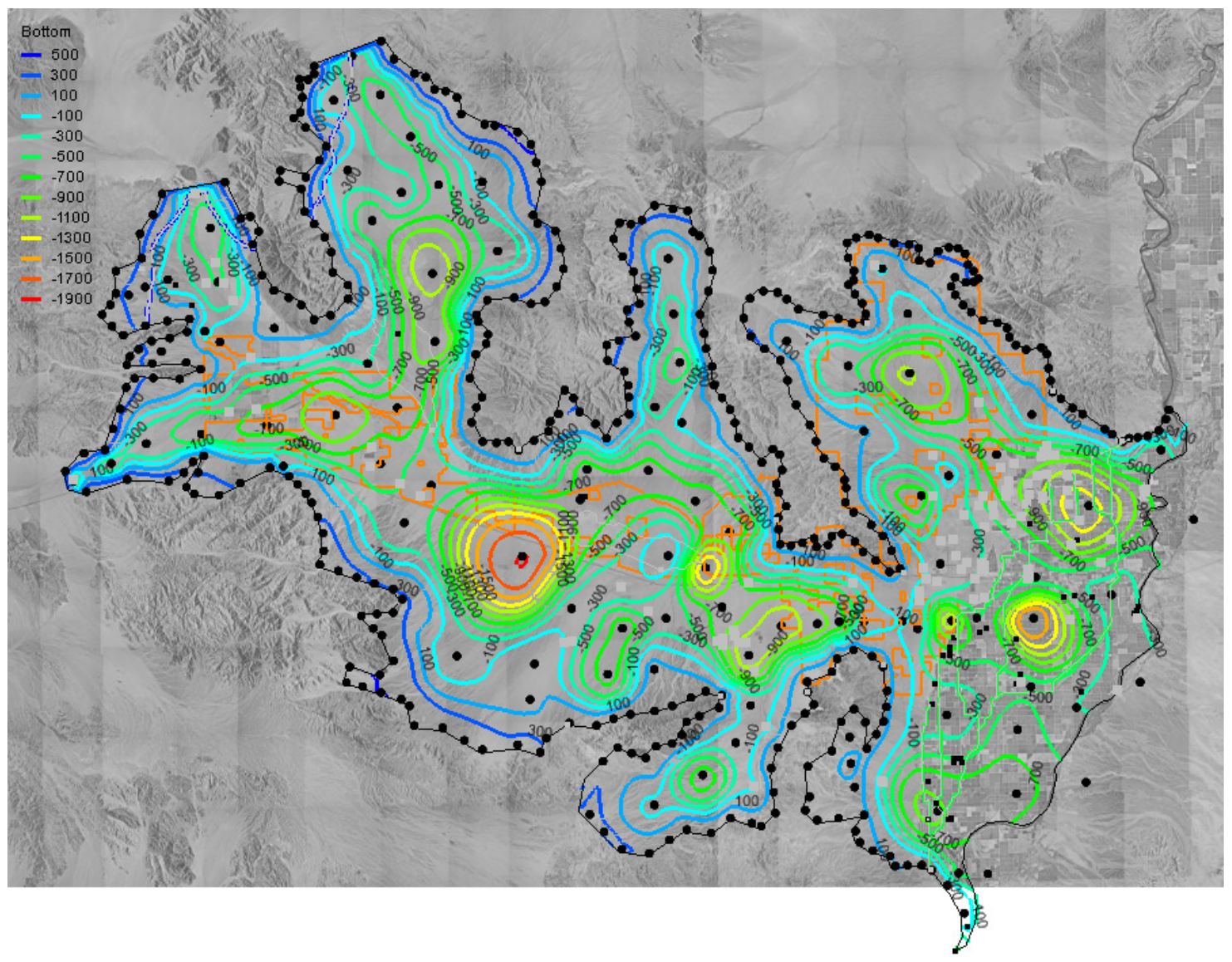

Figure 3 Interpolated Bedrock Elevation Contours Used as the Bottom Surface of the Model (contours are in $\mathbf{m}$, and elevation control points are shown in black) 


\subsection{Hydraulic Conductivity of the Alluvial Fill}

The principal aquifer consists of alluvium, marginal marine, and fanglomerate deposits on top of a metamorphic bedrock basement complex (Metzger et al. 1973; CDWR 2003). The Quaternary age alluvium sediments consist of alluvial fan and river deposits of fine to coarse sands intermixed with layers of gravel, silt, and clay. The underlying Bouse Formation consists of alluvial fan and marine deposits of limestone interbedded with clays, silt, and sand, and it overlies the late Tertiary age fanglomerate deposits (Wilson and Owen-Joyce 1994). These materials have a wide range of hydrogeologic properties, and the properties vary spatially depending on depth and proximity to mountains. Transmissivity values for the principal aquifer have been reported to range from 13 to $94,000 \mathrm{ft}^{2} / \mathrm{d}\left(1.2\right.$ to $8,733 \mathrm{~m}^{2} / \mathrm{d}$ ) (Metzger et al. 1973). When these values are translated into hydraulic conductivity $(\mathrm{K})$ values across the range of estimated depths in this model, the range in $\mathrm{K}$ is approximately 0.026 to $9,400 \mathrm{ft} / \mathrm{d}(0.0002$ to $873 \mathrm{~m} / \mathrm{d})$.

\subsection{Water Budget Estimates}

The Solar PEIS reported a groundwater budget for the Chuckwalla Valley and Palo Verde Mesa basins using the information from the California Department of Water Resources (CDWR) and environmental impact statements for solar developments in the Riverside East SEZ (BLM 2010a,b). CDWR Bulletin 118 characterizes the water budget information for the Chuckwalla Valley and Palo Verde Mesa groundwater basins as being "Type C," meaning few data are available (CDWR 2003). Further analyses have suggested that groundwater recharge is less than previously thought and that overdraft conditions (i.e., groundwater outflow and withdrawals exceeding inputs) have been occurring for decades (Godfrey et al. 2012). The development of the Riverside East SEZ Model involved updating the water budget for the Chuckwalla Valley and Palo Verde Mesa groundwater basins from the values reported in the Solar PEIS to better reflect recent analyses (Greer et al. 2013).

Recharge to the basins occurs as a combination of mountain-front recharge (the infiltration of water in drainages along mountain fronts and direct infiltration of precipitation into mountain blocks), agricultural return flow, streamflow recharge, in-place recharge, and aqueduct leakage. Natural recharge in the Palo Verde Mesa groundwater basin is estimated to be $800 \mathrm{ac}-\mathrm{ft} / \mathrm{yr}$ $\left(2,702 \mathrm{~m}^{3} / \mathrm{d}\right)$ (CDWR 1975). Assuming the same rate per unit area for the other two basins in the modeled area, the total natural recharge for the model area would be 3,200 ac- $\mathrm{ft} / \mathrm{yr}$ $\left(10,800 \mathrm{~m}^{3} / \mathrm{d}\right)$.

Although not documented, leakage is likely from the Colorado River Aqueduct (CRA), which runs across the western edge of the Chuckwalla Valley basin. The CRA began operations in 1942. To estimate potential leakage from the CRA into the Chuckwalla Valley basin, leakage rates were assumed to be similar to leakage rates of the much younger Central Arizona Project (CAP) canal, completed in the early 1990s. In the Ranegras Plain groundwater basin in southwestern Arizona, the CAP canal leaks at an estimated rate of 2,000 to 3,000 ac-ft/yr (6,760 to $10,100 \mathrm{~m}^{3} / \mathrm{d}$ ) (ADWR 2010). For the Brenda SEZ Model of the Ranegras Plain basin (Quinn et al. 2013), CAP leakage was applied as a component of aerially distributed recharge at 
a rate of $2,500 \mathrm{ac}-\mathrm{ft} / \mathrm{yr}\left(8,440 \mathrm{~m}^{3} / \mathrm{d}\right)$. Considering that the CRA is much older than the CAP and that both are of similar lengths within the Riverside East SEZ Model and Brenda SEZ Model, a reasonable initial estimate of CRA leakage in the Chuckwalla basin would be $80 \%$ of the CAP leakage or $2,000 \mathrm{ac}-\mathrm{ft} / \mathrm{yr}\left(6,760 \mathrm{~m}^{3} / \mathrm{d}\right)$. Split between the two segments within the model area, the rates are $900 \mathrm{ac}-\mathrm{ft} / \mathrm{yr}\left(3,040 \mathrm{~m}^{3} / \mathrm{d}\right)$ in the northern portion and $1,100 \mathrm{ac}-\mathrm{ft} / \mathrm{yr}\left(3,720 \mathrm{~m}^{3} / \mathrm{d}\right)$ in the northwest portion.

Documented groundwater inflows to the basins as underflow from adjacent basins are from the Pinto and Orocopia Valleys to the west. The values are presented in Table 1

(Godfrey et al. 2012).

The majority of groundwater withdrawals in the region of the Riverside East SEZ are for agricultural and domestic uses, with an unreported withdrawal from the former Kaiser mining wells in the western Chuckwalla Valley basin. There are 88 identifiable pumping wells in the USGS's National Water Information System (NWIS) database (USGS 2012) that are located within the Riverside East SEZ Model domain. The CDWR estimated that during dry and wet years occurring from 1998 to 2001, total well withdrawals in the basins ranged from 4,400 to $5,700 \mathrm{ac}-\mathrm{ft} / \mathrm{yr}\left(14,860\right.$ to $\left.19,250 \mathrm{~m}^{3} / \mathrm{d}\right)$ (CDWR 2005). For Phases 1 and 2 of this study, pumping was assumed to be the average of the range presented by CDWR (2005), for a total of approximately $5,100 \mathrm{ac}-\mathrm{ft} / \mathrm{yr}\left(17,200 \mathrm{~m}^{3} / \mathrm{d}\right)$. The total pumping rate was divided among each of the 88 identifiable pumping wells, which resulted in a withdrawal rate of approximately $58 \mathrm{ac}-\mathrm{ft} / \mathrm{yr}\left(196 \mathrm{~m}^{3} / \mathrm{d}\right)$ per well.

Table 1 Estimates of Selected Components of Riverside East SEZ Model Inflows and Outflows

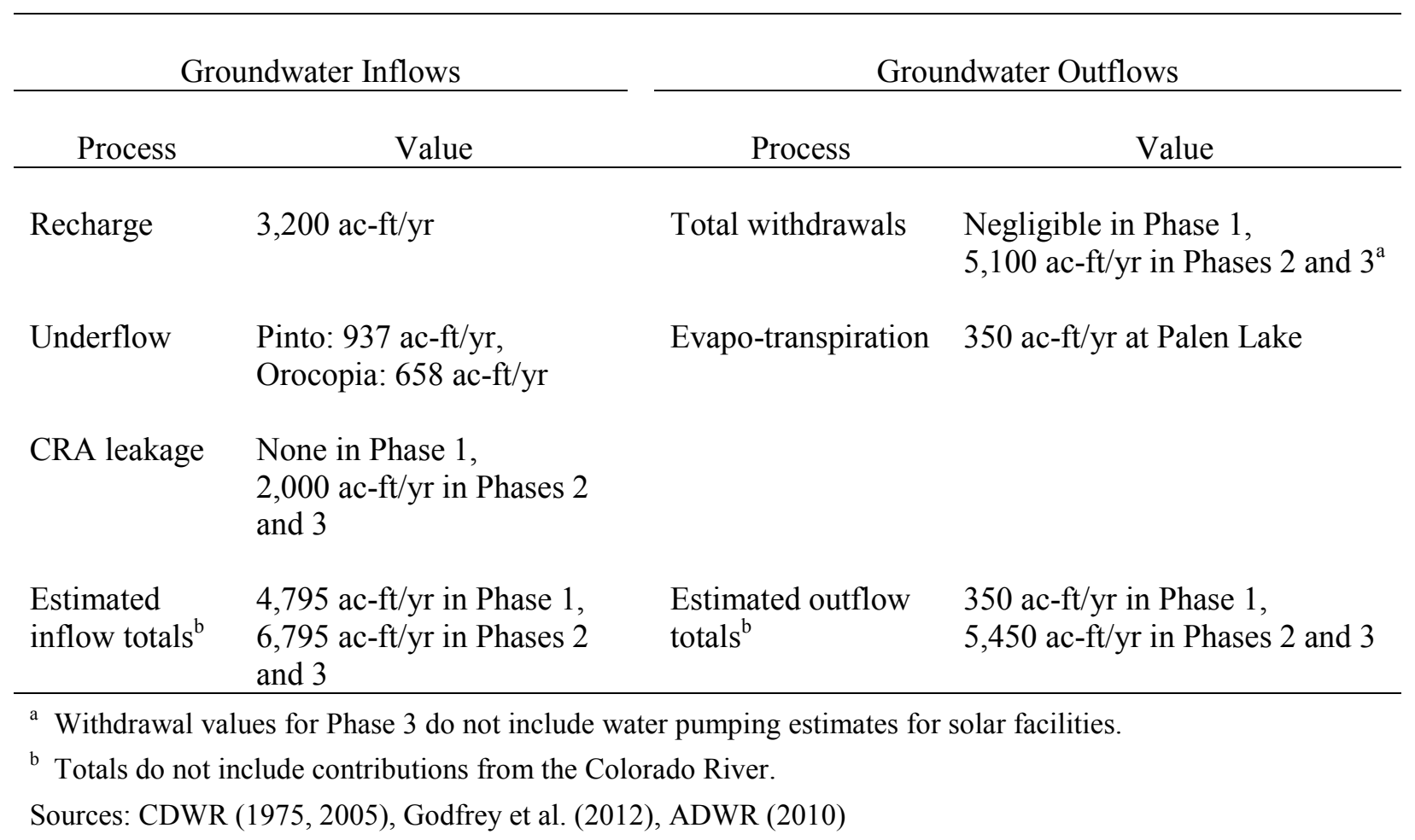


Evapotranspiration rates are estimated for Palen Lake on the basis of information presented in Godfrey et al. (2012). However, the observation of near-surface water levels adjacent to Palen Lake are associated with a local perched water table and are not indicative of the predominant aquifer system in the Chuckwalla Valley; they would not be simulated in this one-layer model structure.

As can be seen in Table 1, the estimated model inflows are larger than the outflows. This is mainly due to the omission of flows related to the Colorado River and Palo Verde Irrigation District (PVID) drainage ditches, which are expected to be predominantly outflows from the study area (through the PVID drainage ditches). Godfrey et al. (2012) summarized and evaluated a range of recharge and discharge estimates for the Chuckwalla Valley basin. There is greater certainty with regard to the recharge estimates on the lower end of the range, indicating that mining of groundwater may have been occurring for decades. For this study, individual inflow, recharge, and evapotranspiration components used in the groundwater model (see Table 1) are in the lower end of the previously reported ranges described by Godfrey et al. (2012). 
This page intentionally left blank. 


\section{MODEL SETUP}

Numerical groundwater modeling (using finite differences) was performed with the USGS code MODFLOW 2000. Several MODFLOW packages were used, including the river (RIV), drain (DRN), and constant-head boundary/time-variant specified head (CHD) packages. Pre- and postprocessing was performed by using Groundwater Modeling System (GMS) software Version 8.3 with support from ArcMap 10.

\subsection{Grid Design}

The grid for the numerical model is designed with a constant cell size of $656 \times 656 \mathrm{ft}(200 \times$ $200 \mathrm{~m}$ ) across the model (Figure 2). The model is created with a single layer. Further groundwater modeling analyses could incorporate lithologic details in a multilayer model, with distributed properties in each layer. Ground surface elevations were obtained in Digital Elevation Model (DEM) format from the USGS (Gesch et al. 2002; Gesch 2007). Geographic information system (GIS) tools in ArcMap 10 were used to reduce the DEM data set to a manageable number of points for use in GMS. GIS tools were also used to determine the layer thickness/depth to bedrock in the model domain. A series of points were traced around the edge of the basins along the alluvium/bedrock boundary, and the ground elevation of each point was determined. Throughout the central portions of the basins, the bedrock elevations were determined at several locations (as described in Section 2.2). These two sets of points were combined, and the elevation of the top of the bedrock was interpolated by using the natural neighbor algorithm (Figure 3). In GMS, the bedrock surface and the ground surface created the boundary of the three-dimensional modeling domain.

\subsection{Boundary Conditions}

The bottom of the flow domain is a no-flow boundary represented by the bedrock surface. Subsurface flow is to the east, originating from a combination of inflows (described above) including the Colorado River Aqueduct (modeled as RIV cells) near the Eagle and Coxcomb Mountains. Subsurface flows discharge to the Palo Verde Irrigation District ditches in the Palo Verde Valley (modeled as DRN cells) and to the Colorado River (modeled as changing head, or CHD, cells). The ditch elevations (i.e., elevations of the DRN cells) were set based on the survey results from the USGS Colorado River Accounting Surface study (Weile et al. 2008). The Colorado River serves as a water source in its upstream portion and as a discharge source in its downstream portion. Other lateral boundaries are no-flow and generally follow the boundary between the alluvium and the bedrock mountains.

\subsection{Layer Discretization}

Aquifer tests performed in the Chuckwalla Valley and Palo Verde Mesa basins exhibited a range of behavior, but the alluvial fill aquifer is treated as unconfined, and this study uses only one model layer. In the Palo Verde Mesa, observation wells indicated both unconfined and semi- 
confined conditions in the Quaternary alluvium and within the Bouse Formation (AECOM 2010b). Tests northwest of Desert Center indicated a similar mix of behaviors within the same formations (GEI Consultants, Inc. 2010). In the central portion of the SEZ near Ford Dry Lake, shallow observation wells in the Quaternary alluvium exhibited unconfined behavior, while deeper wells within the Bouse Formation indicated confined conditions beneath lowpermeability sediments between 185 and $260 \mathrm{ft}(56$ and $79 \mathrm{~m})$ below ground surface (WorleyParsons 2009). These low-permeability sediments are presumed to be related to lacustrine and playa deposits at the base of the Quaternary alluvium and/or distal estuarine deposits at the top of the Bouse Formation at the end of the California embayment (WorleyParsons 2009; Metzger et al. 1973). In either case, low-permeability sediments are present in the valley center, but they are likely to grade laterally into coarser sediments toward the basin margins (Buising 1990, WorleyParsons 2009) and not serve as a confining unit across the entire width of the valley. Using a one-layer approach is thus deemed to be acceptable for this study.

\subsection{Initial Conditions}

With the exception of the changing head boundary imposed along the Colorado River, starting heads in the Phase 1, steady-state, pre-1942 model domain were set to the ground surface elevation and allowed to decline during model iterations. Because of the depth to groundwater, model cells along the edge of the model domain convert to dry cells, as expected. Starting conditions for Phase 2 were the hydraulic heads resulting from the Phase 1 steady-state simulation. Starting conditions for Phase 3 were the hydraulic heads resulting from the Phase 2 calibrated model at the simulation end point in 2011.

\subsection{Calibration Targets}

All field observations for wells within the Riverside East SEZ Model domain were downloaded from the USGS's NWIS database (USGS 2012). For the Phase 1 steady-state simulation, observed hydraulic heads at 5 wells scattered throughout the three basins were used as calibration targets. These were the only measurements found immediately prior to 1942 in the NWIS database. For the Phase 2 transient simulation between 1942 and 2010, 118 wells from the NWIS database and 6 additional wells associated with solar facility hydrogeologic analyses were used (WorleyParsons 2009; West Yost Associates 2011). Heads measured between 2000 and 2010 at these 124 wells were used as the observation points for calibration at the end of the Phase 2 simulation. This was considered sufficient for this study, since water levels were relatively stable in the 1990s and 2000s after partially recovering from relatively depressed levels in the 1980s. 


\section{RESULTS AND DISCUSSION}

\subsection{Phase 1 - Steady-State Model}

Hydraulic conductivity, $\mathrm{K}$, was varied manually across the model in seven zones in order to match the pre-1942 target hydraulic head values at five observation points in the basins and to optimize model convergence. Zones with similar $\mathrm{K}$ values were manually delineated, and $\mathrm{K}$ values were iteratively adjusted based on a combination of hydrostratigraphic information (e.g., higher K values in the Palo Verde Valley basin trending to lower K values away from the river) and optimization to corresponding observed heads (e.g., lower $\mathrm{K}$ values near Palen Lake to match a higher observed head) at the five observation points. The resulting $\mathrm{K}$ values ranged from 0.3 to $52 \mathrm{ft} / \mathrm{d}(0.1$ to $15.85 \mathrm{~m} / \mathrm{d})$. Calibrated heads and K-zones are shown in Figure 4a. Recharge values were varied only slightly in the Phase 1 simulation, but no improvement in performance was seen. Therefore, calibration did not result in a change in recharge values from the initial estimate of 3,200 ac- $\mathrm{ft} / \mathrm{yr}\left(10,800 \mathrm{~m}^{3} / \mathrm{d}\right)$. The head targets for Phase 1 had minimal errors (Figure 4b). The water budget error for Phase 1 in the MODFLOW model was $0.00 \%$.

\subsection{Phase 2 - Transient Model}

The Phase 2 transient model, representing decades of agricultural, mining, and municipal pumping, was used to simulate the changes in groundwater elevations between the start of CRA operation in 1942 and recent conditions (2000 to 2010). The transient model was designed with 69 one-year time steps representing 69 years of averaged annual agricultural, mining, and municipal pumping at 5,100 ac-ft/yr $\left(17,200 \mathrm{~m}^{3} / \mathrm{d}\right)$ (Table 2). This is a simplification of actual, annually varying pumping, but it is considered suitable for creating the initial conditions for the Phase 3 simulation.

A specific yield of 0.1 was applied to all model cells. This value is based on previous work (Weile et al. 2008; Leake et al. 2008; WorleyParsons 2009; AECOM 2010a,b; GEI Consultants, Inc. 2010) that used a range of 0.05 to 0.2 for specific yield within the three modeled basins (Table 2).

The spatially-variable K and recharge distributions were calibrated by using the MODFLOW Parameter Estimation Tool (PEST) utility. The pilot point method was used in the PEST utility; it interpolates values from a set of starting points (called pilot points) and inversely tries to match calculated head values with head values taken from monitoring wells (called observation points). Eighteen pilot points were chosen, and their starting $\mathrm{K}$ and recharge values were derived from the results of the Phase 1 simulation. The PEST inverse model initially interpolated between the starting pilot point values so that values varied from cell to cell throughout the model. When the inverse model ran, the values at the pilot points were iteratively adjusted and re-interpolated to the grid cells to produce a set of simulated heads calibrated to the 124 observation points described in Section 3.5. The majority of the Phase 2 model area had PEST-derived K values (Figure 5) that were similar to $\mathrm{K}$ values reported in aquifer tests or were from previous groundwater models calibrated to aquifer test results (Table 2; Leake et al. 2008; WorleyParsons 2009; AECOM 2010a,b; GEI Consulants, Inc. 2010). 
(a)

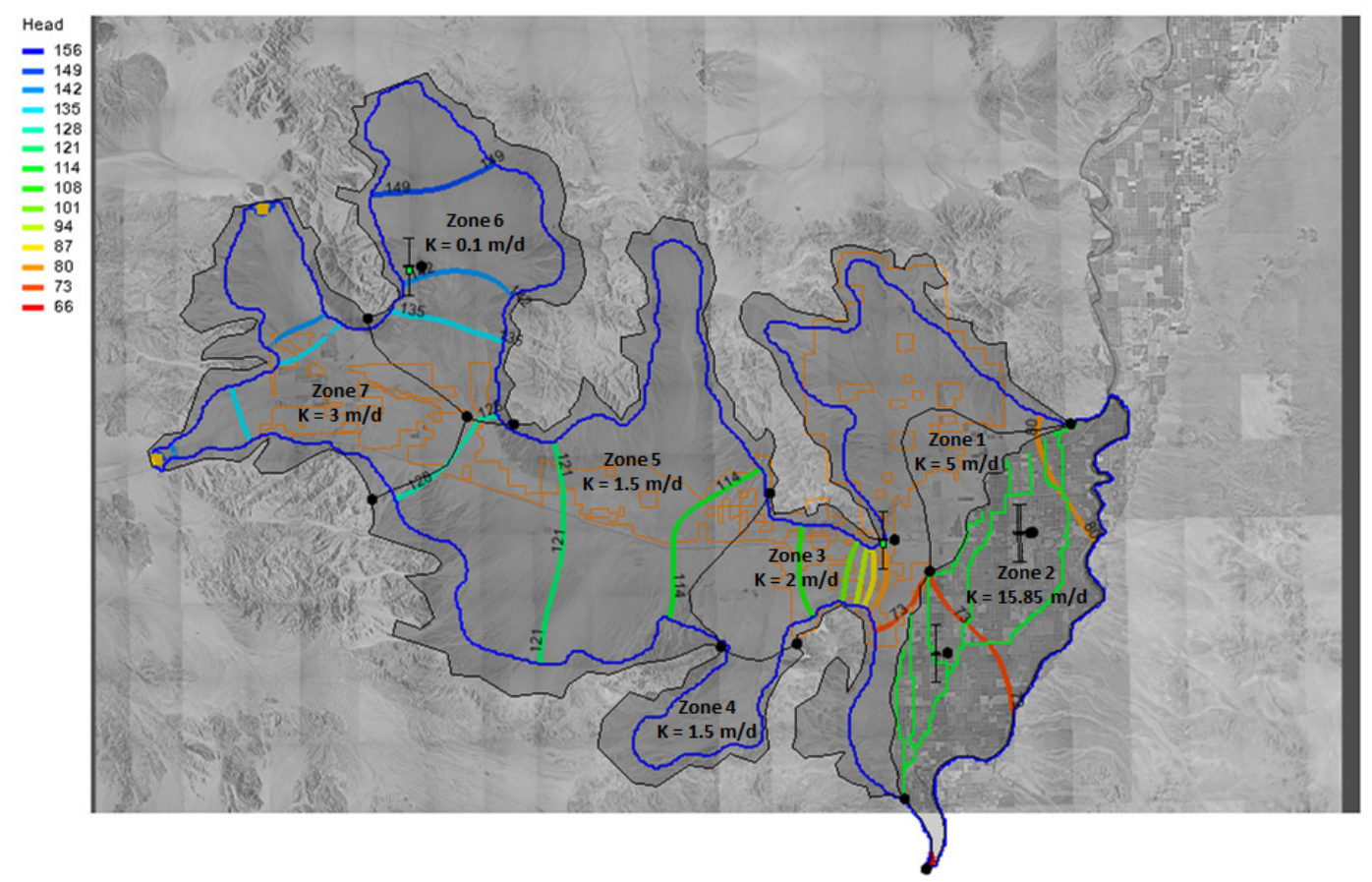

(b)

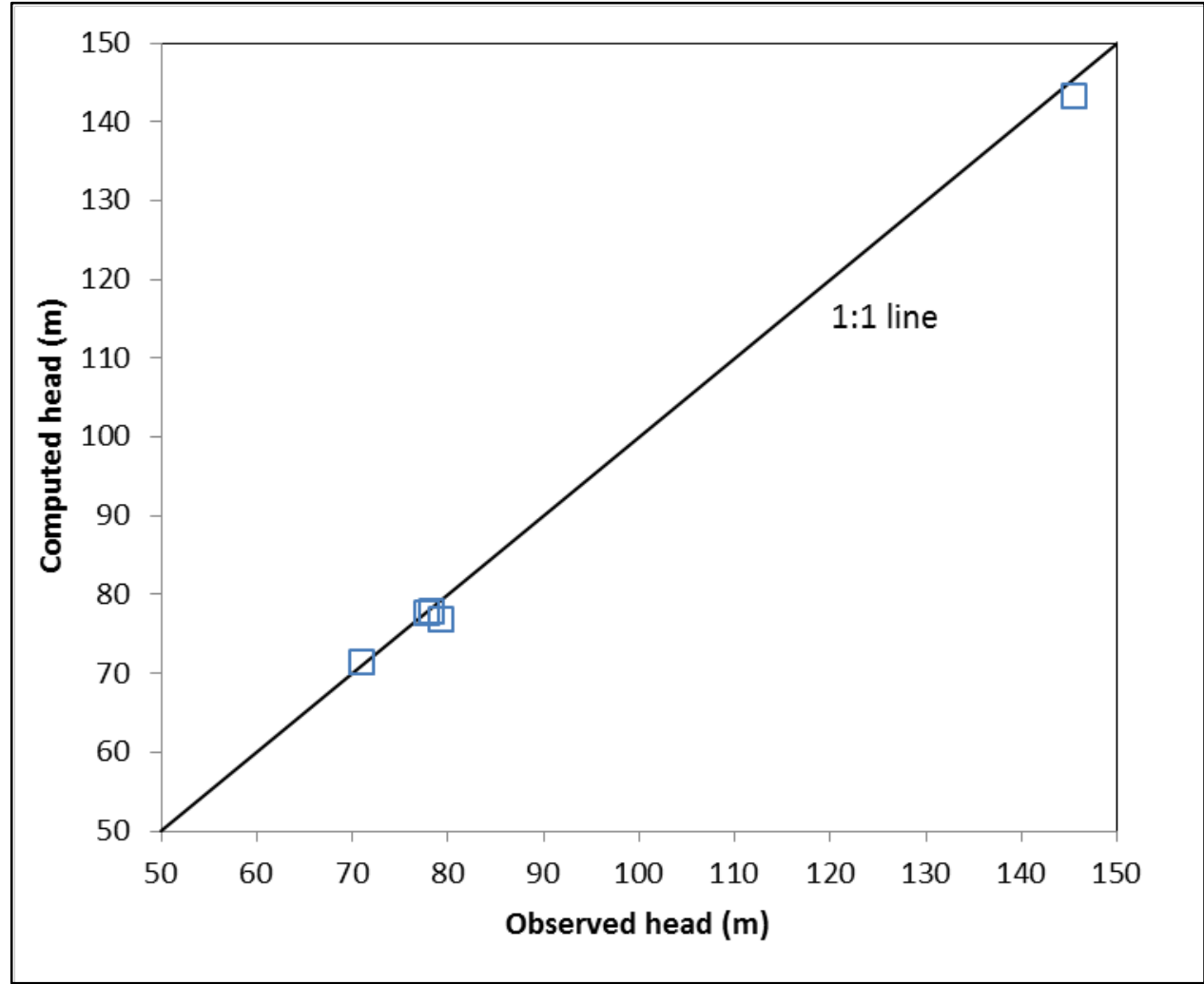

Figure 4 (a) Calibrated Pre-1942 Steady-State Head Contours (in m) (blue outline defines the saturated extent, K-zones are outlined in black with labels, and the five observation points are identified by statistical error bars, $+/-10 \mathrm{~m}$, lined in black) and (b) Computed Versus Observed Heads at Observation Points for the Pre-1942 Steady-State Model 
Table 2 Comparison of Selected Variables from Groundwater Flow Models Developed across the Riverside East SEZ

\begin{tabular}{|c|c|c|c|c|c|c|}
\hline Variable & This Study & $\begin{array}{c}\text { Eagle Mountain } \\
\text { Pumped Storage } \\
\text { Project } \\
\end{array}$ & Desert Sunlight Solar & Genesis Solar & Blythe Solar & $\begin{array}{c}\text { USGS Accounting } \\
\text { Surface }\end{array}$ \\
\hline Citation & & $\begin{array}{l}\text { GEI Consultants } \\
(2010)\end{array}$ & AECOM (2010a) & WorleyParsons (2009) & AECOM (2010b) & Leake et al. (2008) \\
\hline Model type & 1-layer head & $\begin{array}{l}\text { Analytical: Taylor } \\
\text { series approximation } \\
\text { to the Theis nonequil- } \\
\text { ibrium well function }\end{array}$ & $\begin{array}{l}\text { 1-layer superposition } \\
\text { modified (Leake et al. } \\
2008 \text { ) }\end{array}$ & $\begin{array}{l}\text { 13-layer (L1-L13) } \\
\text { superposition }\end{array}$ & $\begin{array}{l}\text { 1-layer } \\
\text { superposition } \\
\text { modified (Leake } \\
\text { et al. 2008) }\end{array}$ & $\begin{array}{l}\text { 1-layer } \\
\text { superposition }\end{array}$ \\
\hline Notes & & $\begin{array}{l}\text { Low-K deposits } \\
\text { (through } 900 \mathrm{ft} \text { deep) } \\
\text { were assumed to } \\
\text { preclude a lower } \\
\text { aquifer zone; thus, b is } \\
\text { only } 150 \mathrm{ft} \text {, but some } \\
\text { wells there are up to } \\
1,300 \mathrm{ft} \text { deep }\end{array}$ & $\begin{array}{l}\text { Considered four zones: } \\
\text { Zone 1: western } \\
\text { Chuckwalla Valley, } \\
\text { Zone 2: central } \\
\text { Chuckwalla Valley, } \\
\text { Zone 3: eastern } \\
\text { Chuckwalla Valley, and } \\
\text { Zone 4: Palo Verde } \\
\text { Mesa }\end{array}$ & $\begin{array}{l}\text { K's and T's derived } \\
\text { using method described } \\
\text { by Driscoll (1986). } \\
\text { Confining unit } \\
\text { interpreted from } \\
\text { geophysical data in } \\
\text { valley center and } \\
\text { applied over valley } \\
\text { width. }\end{array}$ & $\begin{array}{l}\text { Considered two } \\
\text { scenarios with a } \\
\text { low and a high } \\
\text { transmissivity }\end{array}$ & $\begin{array}{l}\text { Considered two } \\
\text { scenarios with a } \\
\text { low and a high } \\
\text { transmissivity }\end{array}$ \\
\hline $\begin{array}{l}\text { Hydraulic } \\
\text { conductivity, K }\end{array}$ & $\begin{array}{l}0.002- \\
505 \mathrm{ft} / \mathrm{d} ; 90 \% \\
\text { of model is in } \\
0.3-328 \mathrm{ft} / \mathrm{d} \\
\text { range }\end{array}$ & $\begin{array}{l}25-125 \mathrm{ft} / \mathrm{d} \text {; } \\
\text { Lakebeds: } 0.02- \\
7.1 \mathrm{ft} / \mathrm{d}\end{array}$ & $\begin{array}{l}\text { Zone 1: } 12.6-57 \mathrm{ft} / \mathrm{d} \\
\text { Zone } 2: 2-7 \mathrm{ft} / \mathrm{d} \\
\text { Zone 3: } 12.6-42 \mathrm{ft} / \mathrm{d} \\
\text { Zone 4: } 52-173 \mathrm{ft} / \mathrm{d}\end{array}$ & $\begin{array}{l}\text { Alluvium: } 30 \mathrm{ft} / \mathrm{d} \\
\text { Bouse: } 2 \times 10^{-4} \text { to } \\
14 \mathrm{ft} / \mathrm{d} \\
\text { Fanglomerate: } 15 \mathrm{ft} / \mathrm{d}\end{array}$ & $12.6 \mathrm{ft} / \mathrm{d}, 52 \mathrm{ft} / \mathrm{d}$ & $12.6 \mathrm{ft} / \mathrm{d}, 52 \mathrm{ft} / \mathrm{d}$ \\
\hline Transmissivity, $\mathrm{T}$ & & $7,486 \mathrm{ft}^{2} / \mathrm{d}$ & $\begin{array}{l}\text { Zone } 1: 6,300- \\
8,500 \mathrm{ft}^{2} / \mathrm{d} \\
\text { Zone } 2: 1,000 \mathrm{ft}^{2} / \mathrm{d} \\
\text { Zone } 3: 6,300 \mathrm{ft}^{2} / \mathrm{d} \\
\text { Zone } 4: 26,000 \mathrm{ft}^{2} / \mathrm{d}\end{array}$ & & $\begin{array}{l}6,300 \mathrm{ft}^{2} / \mathrm{d} \\
26,000 \mathrm{ft}^{2} / \mathrm{d}\end{array}$ & $\begin{array}{l}6,300 \mathrm{ft}^{2} / \mathrm{d} \\
26,000 \mathrm{ft}^{2} / \mathrm{d}\end{array}$ \\
\hline Specific yield & 0.1 & 0.05 & $\begin{array}{l}\text { Zone 1: } 0.05-0.2 \\
\text { Elsewhere: } 0.2\end{array}$ & $\begin{array}{l}\text { Alluvium: } 0.15 \\
\text { Bouse \& fanglomerate: } \\
5 \times 10^{-7} \text { to } 2 \times 10^{-5}\end{array}$ & 0.2 & 0.2 \\
\hline
\end{tabular}


Table 2 (Cont.)

\begin{tabular}{cccccc}
\hline Variable & This Study & $\begin{array}{c}\text { Eagle Mountain } \\
\text { Pumped Storage } \\
\text { Project }\end{array}$ & Desert Sunlight Solar & Genesis Solar & Blythe Solar \\
\hline Aquifer thickness & $\begin{array}{l}\text { Variable, } 33 \\
\text { to }>5,280 \mathrm{ft}\end{array}$ & 150 to $300 \mathrm{ft}$ & $\begin{array}{l}\text { Two scenarios: } \\
500 \mathrm{ft} \text { and } 150 \mathrm{ft}\end{array}$ & $\begin{array}{l}\text { Constant for L1-L11 } \\
\text { (10 to } 420 \mathrm{ft}) ; \text { varies } \\
\text { with bedrock elevation } \\
\text { for L12-L13 (<600 ft to } \\
\text { bedrock surface range) }\end{array}$ \\
\hline
\end{tabular}




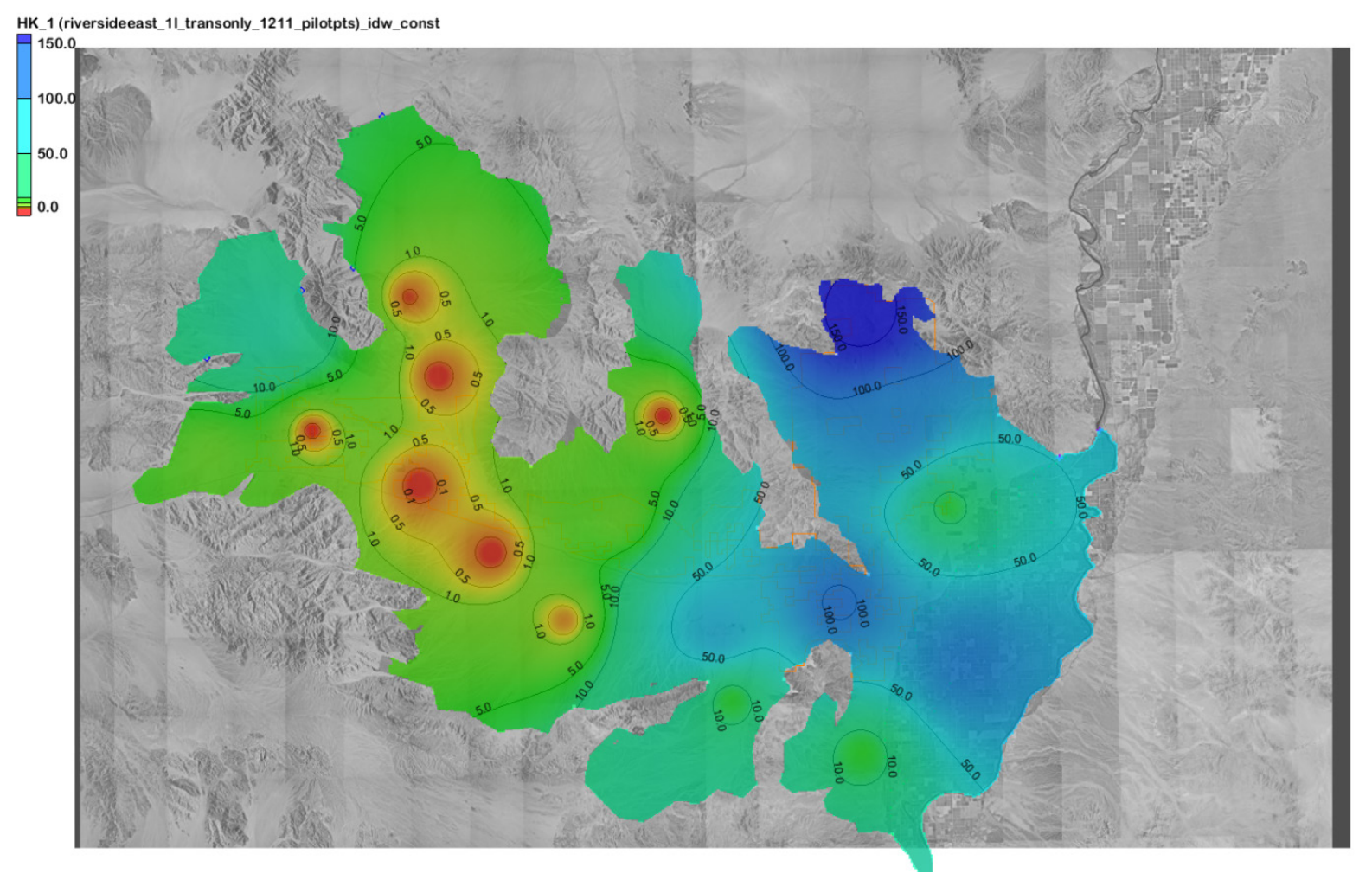

Figure 5 Distribution of Hydraulic Conductivity from the Calibration of the Transient
1942-2010 Model Using PEST (contours in m/d)

Due to the increased number of observation points and calibration parameters between the Phase 1 steady-state model ( 5 observation points and $7 \mathrm{~K}$ zones) and the Phase 2 transient model (124 observation points and 18 pilot points for both $\mathrm{K}$ and recharge), there is a wider variability in the calibrated K values for Phase 2, ranging from 0.002 to $505 \mathrm{ft} / \mathrm{d}(0.00061$ to $158.6 \mathrm{~m} / \mathrm{d})$ (Figure 5), than in those for Phase 1 (Figure 4a). Only isolated locations immediately adjacent to PEST pilot points had K values that were either less than $0.3 \mathrm{ft} / \mathrm{d}(0.1 \mathrm{~m} / \mathrm{d})$ or greater than $328 \mathrm{ft} / \mathrm{d}(100 \mathrm{~m} / \mathrm{d})$ in the Phase 2 model. Recharge values did not change from the Phase 1 values as a result of the PEST process.

Final hydraulic heads from the Phase 2 transient model indicated a shallow gradient in the eastern half of the Chuckwalla Valley and a steeper gradient in the western half to match the higher groundwater elevations observed near Desert Center (Figure 6a). This finding is consistent with expectations. The target heads for Phase 2 are values from 124 wells scattered throughout the basin. However, the range of observation dates at each well varies between 2000 and 2010; the values do not represent a single snapshot in recent time. In addition, the head measurements may be affected by localized hydrogeology, perching, well construction, well depth, and proximity to localized concentrated recharge (e.g., from major washes or the CRA). Therefore, model results at the end of the 69-year period were inspected and compared to recent heads in the study area. Despite the noise in the target head values, it was determined that the 
(a)

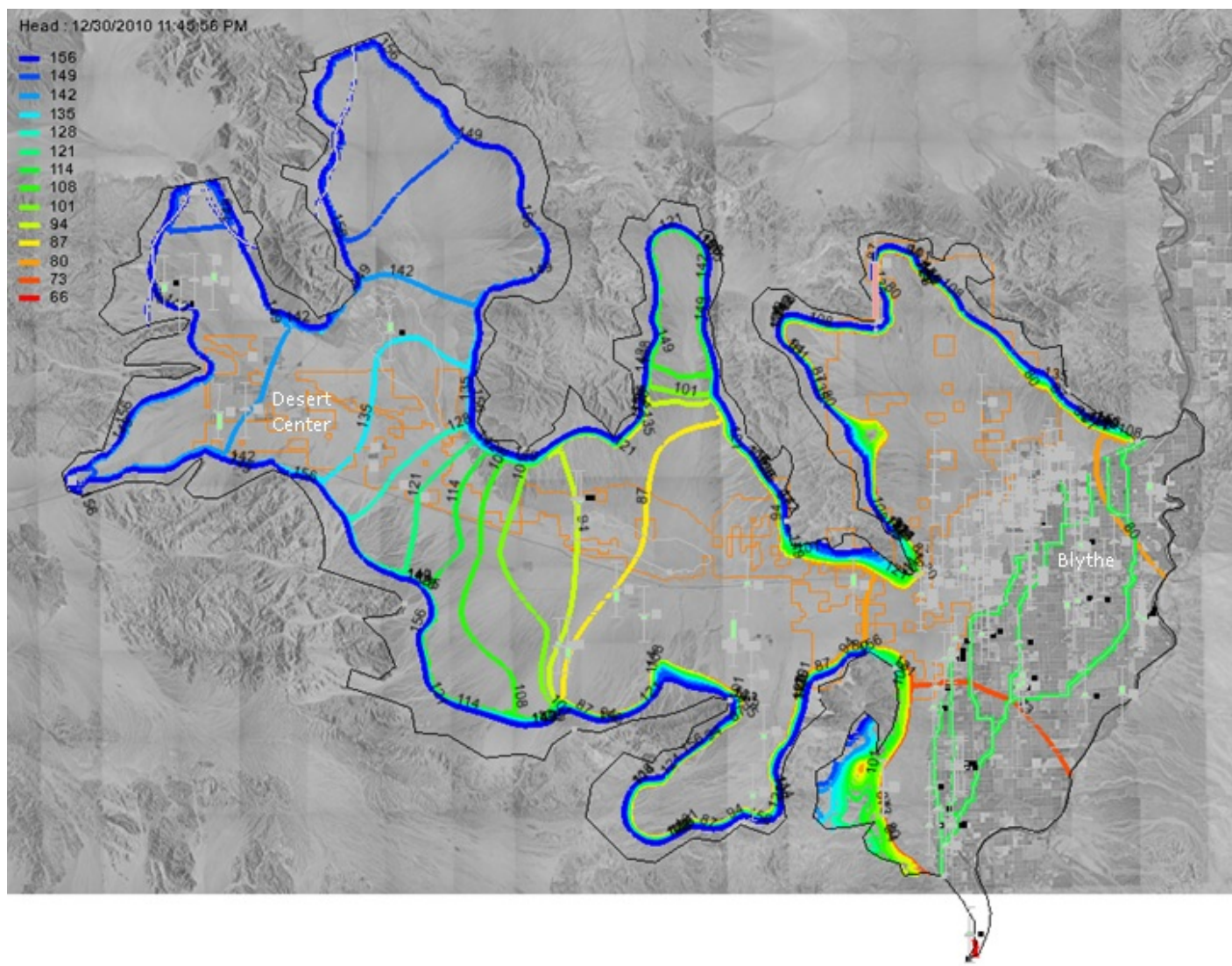

(b)

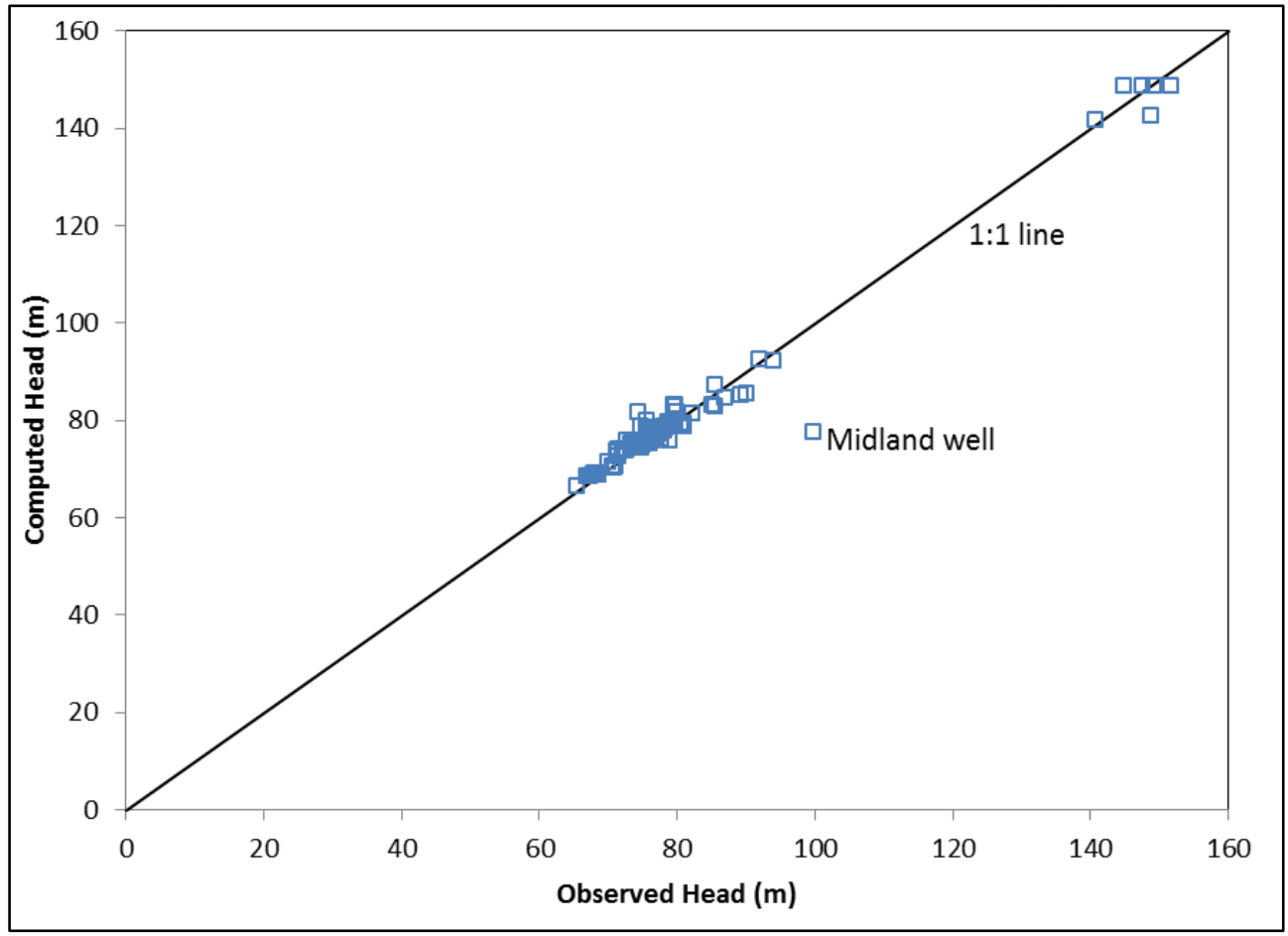

Figure 6 (a) Transient Model Estimated Heads after 69 Years of Agricultural, Mining, and Municipal Pumping (contours in m) between 1942 and 2010; (b) Calibration Results for the Final Time Step of the Phase 2 Model (the outlier point is from the Midland well at the northern border of the Palo Verde Mesa groundwater basin) 
Phase 2 final heads (Figure 6b) matched the observed target heads adequately. An outlier value was identified (a well with a 99-m observed head) near the former town of Midland, located at the northern border of the Palo Verde Mesa.

\section{Model Sensitivity}

PEST is an optimization tool that aims to match the simulated groundwater elevations with an observed set of groundwater elevations by minimizing the weighted sum of squared differences between the two. The optimization problem is iteratively solved by linearizing the relationship between the model's output and its input parameters (in this case, $\mathrm{K}$ and recharge). The linearization is conducted using a Taylor series expansion, where the partial derivatives of each model output with respect to every parameter must be calculated in each iteration. These derivatives provide a measure of the parameter sensitivities, and the "composite sensitivity" is provided by PEST.

Figure 7 shows the results of the sensitivity analysis for $\mathrm{K}$ and recharge values at each of the 18 pilot point locations. The model is most sensitive to $\mathrm{K}$ at the pilot points located along the central flow path through the Chuckwalla Valley and relatively insensitive to the recharge parameters.

\subsection{Phase 3 - Transient Model with Solar Development}

The potential groundwater withdrawal rates at an SEZ depend on the type of technology and the level of development at the SEZ. Three levels of withdrawals were considered for the Phase 3 simulations. The high-water-demand scenario has a total withdrawal of $16,898 \mathrm{ac}-\mathrm{ft} / \mathrm{yr}$ $\left(57,090 \mathrm{~m}^{3} / \mathrm{d}\right)$, representing full build-out of dry-cooled, concentrated solar power facilities. The second scenario has a medium value of $8,450 \mathrm{ac}-\mathrm{ft} / \mathrm{yr}\left(28,550 \mathrm{~m}^{3} / \mathrm{d}\right)$, pumping half of the highwithdrawal scenario. The low-pumping scenario of $672 \mathrm{ac}-\mathrm{ft} / \mathrm{yr}\left(2,270 \mathrm{~m}^{3} / \mathrm{d}\right)$ is for full build-out of photovoltaic facilities. These rates are for the operational stage of solar facility implementation as defined in the Solar PEIS (BLM and DOE 2012); they do not include groundwater withdrawal estimates for construction and reclamation activities. In addition to the high-, medium-, and low-water-demand withdrawal rates, the baseline pumping from the Phase 2 calibrated transient model (i.e., 5,100 ac-ft/yr [17,200 m/d]) was included in the Phase 3 model.

\section{High-Water-Demand Withdrawal Scenario}

To evaluate worst-case conditions from 20 years of SEZ pumping, the high-water-demand withdrawal rate was applied from 2011 to 2030 and divided equally among 19 assumed well locations within the SEZ boundary, resulting in a rate of $889 \mathrm{ac}-\mathrm{ft} / \mathrm{yr}\left(3,000 \mathrm{~m}^{3} / \mathrm{d}\right)$ per well. The locations of the assumed pumping wells in the SEZ can be seen in Figures 8, 9, and 10. The only portion of the Riverside East SEZ not containing simulated pumping wells in these scenarios is the SEZ area to the northeast of McCoy Wash on the Palo Verde Mesa. 
(a) Relative sensitivity to hydraulic conductivity at PEST pilot points

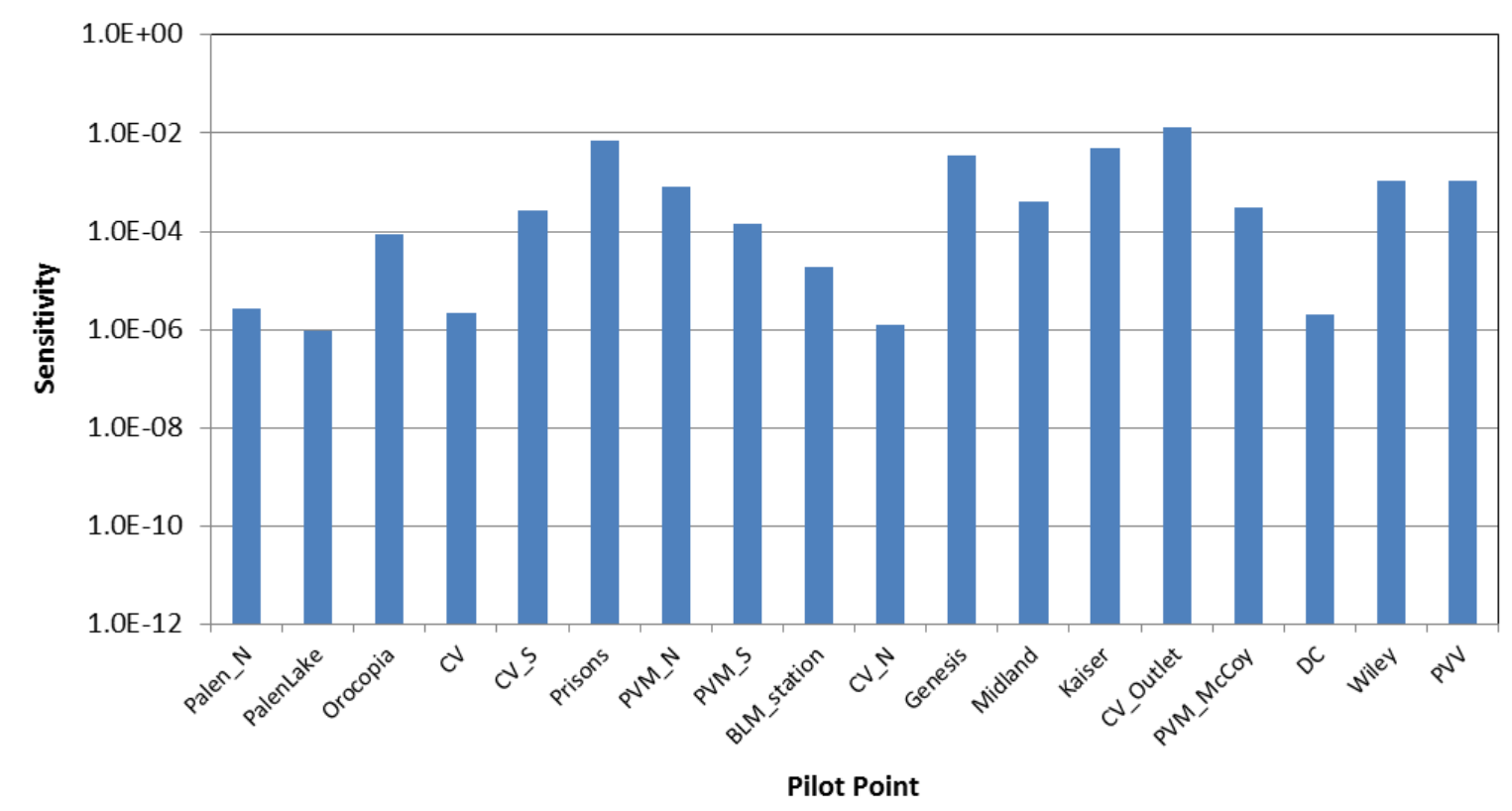

(b) Relative sensitivity to recharge at PEST pilot points

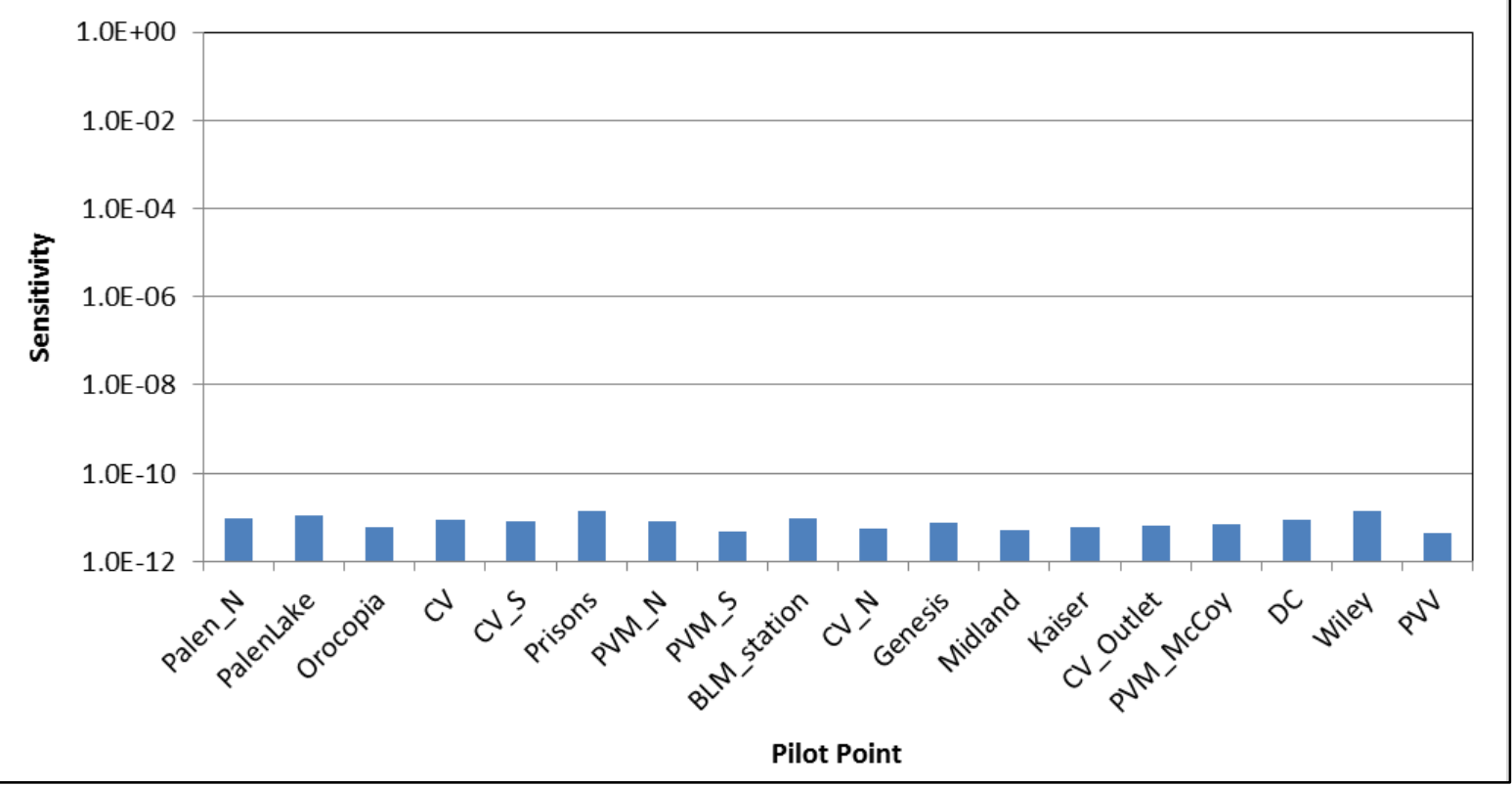

Figure 7 Relative Sensitivities of the Transient Model to (a) Hydraulic Conductivity and (b) Recharge at Pilot Points Used in the PEST Calibration Process 
The simulated distribution of hydraulic heads in 2030 resulting from the withdrawals associated with the high-water-demand scenario (Figure 8) indicates a general west-to-east flow, but with several deflections in the groundwater contours within the Chuckwalla Valley. There is a major decrease in groundwater elevations south of Palen Lake (as indicated by upgradient deflections in the elevation contours), with minor deflections north of Ford Dry Lake and east of the town of Desert Center. Additional modeling was conducted to examine the relative difference between the combined effect of SEZ pumping and baseline pumping (from agricultural, mining, and municipal wells) and the effect of baseline pumping alone during the Phase 3 time frame. The results show that after 20 years, the drawdown attributed to withdrawals from the SEZ may be up to $131 \mathrm{ft}(40 \mathrm{~m})$ at the center of the major cone of depression south of Palen Lake and over $6.5 \mathrm{ft}$ $(2 \mathrm{~m})$ across most of the Chuckwalla Valley basin, with higher drawdown in the western portion of the basin (Figure 9). The simulated groundwater drawdown results are consistent with the one-dimensional analysis presented in the Solar PEIS that suggested there was a potential for

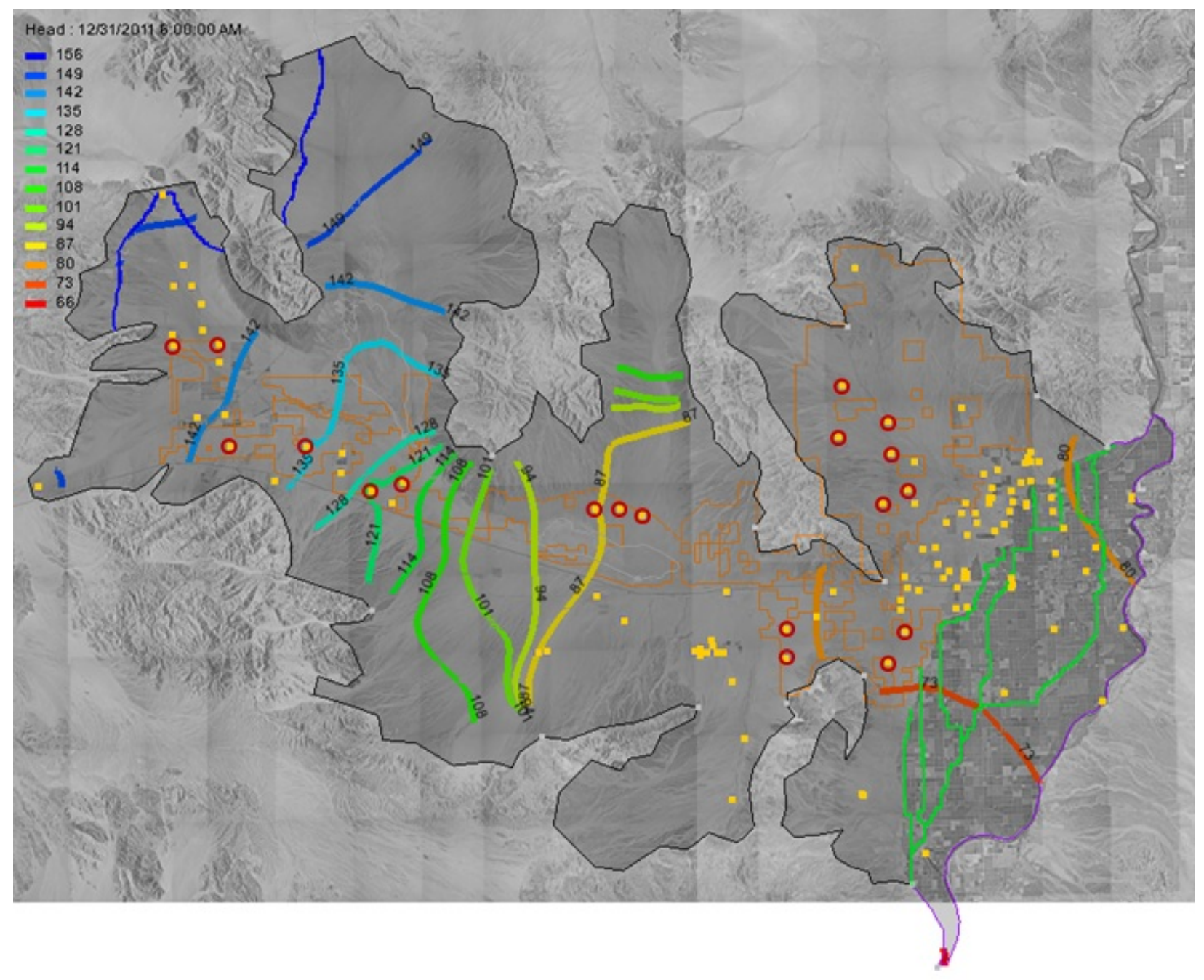

Figure 8 Calculated Heads after 20 Years of SEZ Pumping Considering the High-Water-Demand Scenario in Addition to Withdrawals for Agricultural, Mining, and Municipal Uses (contours in m) (pumping wells are yellow squares, with SEZ wells highlighted by red circles) 


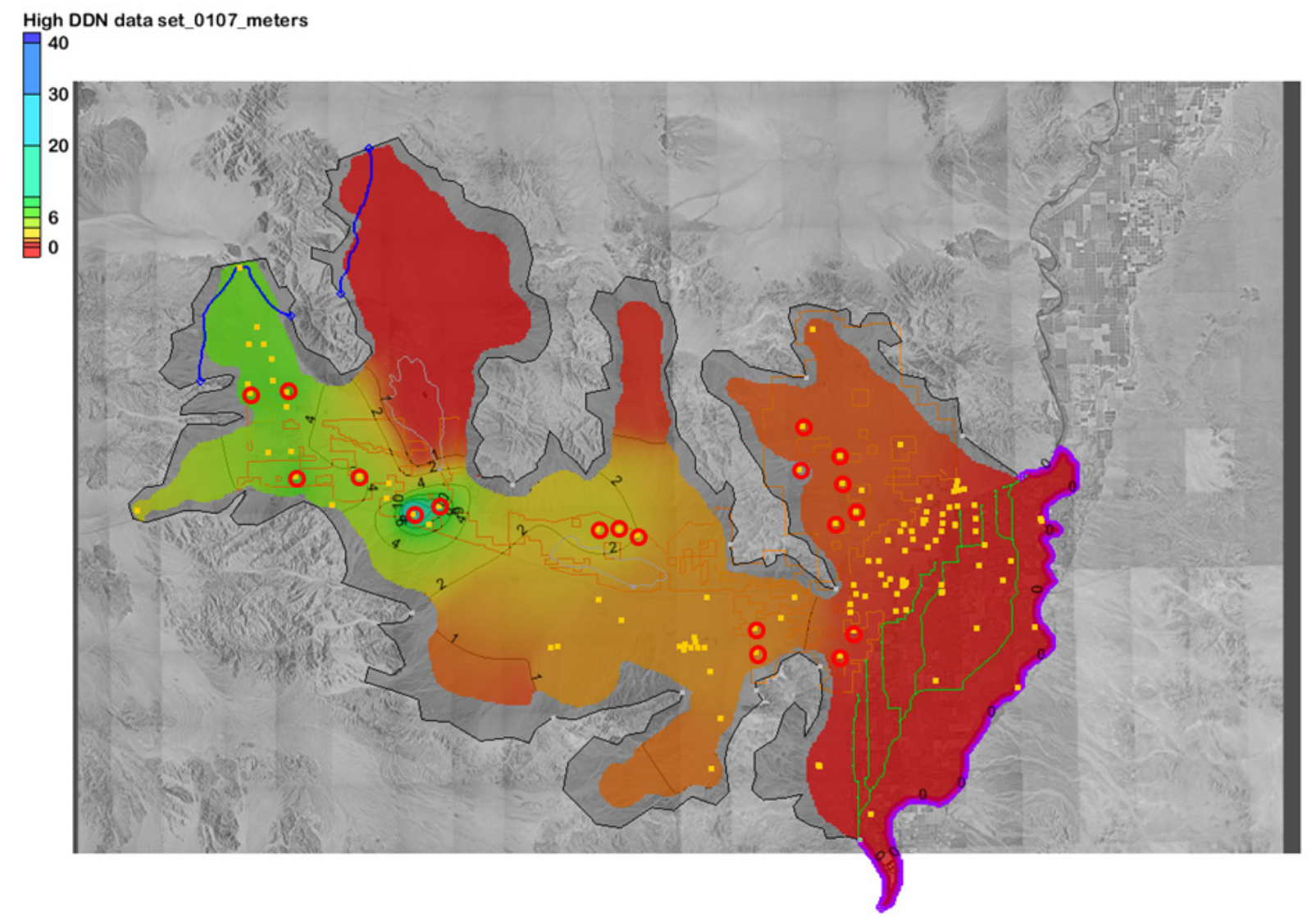

Figure 9 Additional Drawdown Due to a Simulated 20 Years of SEZ Pumping Considering the High-Water-Demand Scenario (contours in $\mathbf{m}$ ) (pumping wells are yellow squares, with SEZ wells highlighted by red circles)

drawdown to exceed $100 \mathrm{ft}(30 \mathrm{~m})$ but that the majority of the SEZ would see drawdown values on the order of tens of feet (BLM and DOE 2012). The sharp increase in drawdown south of Palen Lake is directly attributable to the rate of pumping combined with the decrease in hydraulic conductivity in the western half of the Chuckwalla Valley during the PEST calibration process. Groundwater and geophysical investigations near Ford Dry Lake (WorleyParsons 2009) indicate that there is a considerable thickness of low-permeability sediment between 185 and $260 \mathrm{ft}(56$ and $79 \mathrm{~m})$ below the ground surface in the center of the valley in this area. The Genesis solar wells are installed below this low-permeability zone. The effect shown in this model scenario likely overstates the maximum drawdown effect due to the simplification of the basin hydrostratigraphy. Any additional hydrogeological information obtained in the basins and incorporated into the model would change the outcome of this simulation and the estimate of drawdown from pumping.

Even under conditions representing withdrawal rates for the high-water-demand scenario, the final simulated heads are above the Colorado River Accounting Surface. As seen in Figure 8, the elevation contour ( $73 \mathrm{~m}$, or $239.5 \mathrm{ft}$ ) equivalent to the Accounting Surface elevation for the Chuckwalla Valley (238-240 ft) is located downgradient in the Palo Verde Mesa and Palo Verde Valley groundwater basins. 
The simulated groundwater elevations in the Palo Verde Mesa portion of the SEZ (242.8$282.2 \mathrm{ft}$ or $74-86 \mathrm{~m})$ are also above the Accounting Surface elevations for that area $(218-274 \mathrm{ft}$ or $66-84 \mathrm{~m})$.

Decreases in the water level in the western portion of the Chuckwalla Valley could potentially affect phreatic vegetative communities in this region, particularly in the area to the south of Palen Lake that shows significant drawdown as a result of the high-water-demand scenario.

\section{Medium-and Low-Water-Demand Withdrawal Scenarios}

For the medium-water-demand scenario, each of the 19 SEZ pumping wells was assumed to pump at a rate of $445 \mathrm{ac}-\mathrm{ft} / \mathrm{yr}\left(1,500 \mathrm{~m}^{3} / \mathrm{d}\right)$ from 2011 to 2030 . After 20 years of groundwater withdrawals from the SEZ under the medium-water-demand scenario, the additional drawdown in the basin was a maximum of $39 \mathrm{ft}(12 \mathrm{~m})$ south of Palen Lake but less than $6.5 \mathrm{ft}(2 \mathrm{~m})$ elsewhere in the SEZ (Figure 10). Although the drawdown is less than that seen in the highwater-demand scenario, there could be impacts on phreatic vegetation in areas that experience large drawdowns as a result of the pumping for the medium-water-demand scenario.

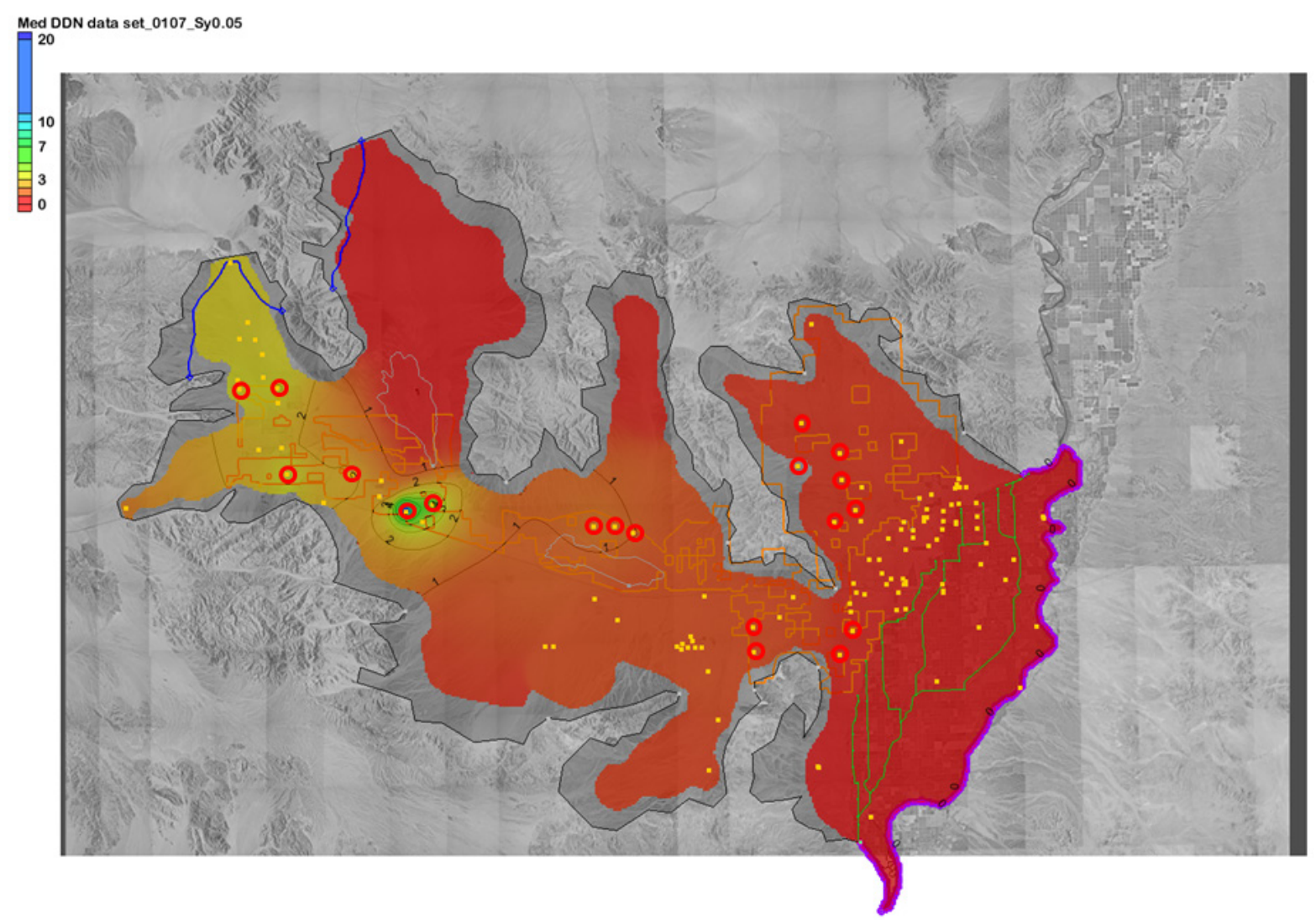

Figure 10 Additional Drawdown Due to a Simulated 20 Years of SEZ Pumping Considering the Medium-Water-Demand Scenario (contours in $\mathbf{m}$ ) (pumping wells are yellow squares, with SEZ wells highlighted by red circles) 
For the low-water-demand scenario, the per-well withdrawal rate was $35 \mathrm{ac}-\mathrm{ft} / \mathrm{yr}\left(118 \mathrm{~m}^{3} / \mathrm{d}\right)$. After 20 years when there were withdrawals from the SEZ under the low-water-demand scenario, the additional groundwater drawdown was small (Figure 11). Impacts are anticipated to be very small as a result of pumping for the low-water-demand scenario.

\subsection{Summary}

The Riverside East SEZ Model is a single layer model that simplifies the geology of the Chuckwalla Valley and the Palo Verde Mesa groundwater basins. The model was developed by using available data on the aquifer characteristics and on hydrologic processes that establish initial and boundary conditions. Recent analyses and additional information about the groundwater budget that differs from the information presented in the Solar PEIS were incorporated into the model development (BLM and DOE 2012). In particular, the recharge and underflow values given in previous presentations are now thought to be too high; the values presented here are lower and represent the BLM's most current understanding of the basins (Godfrey et al. 2012). The Riverside East SEZ Model provides a three-dimensional representation of groundwater drawdown that was not accounted for in the Solar PEIS analysis. The Solar PEIS presented a one-dimensional analysis of drawdown. This effort, however,

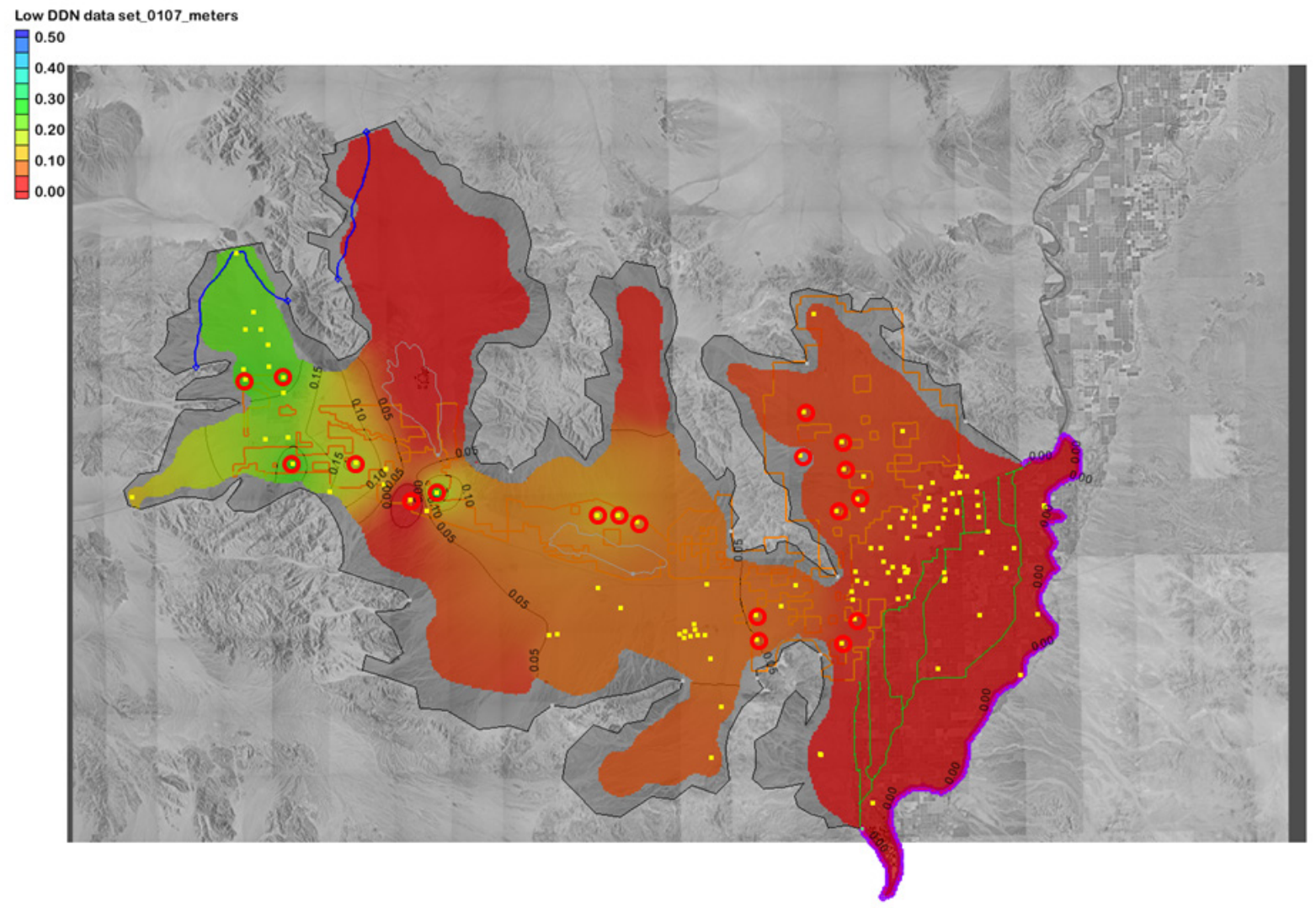

Figure 11 Additional Drawdown Due to a Simulated 20 Years of SEZ Pumping Considering the Low-Water-Demand Scenario (contours in $\mathrm{m}$ ) (pumping wells are yellow squares, with SEZ wells highlighted by red circles) 
provides a more detailed approach, including representation of variable hydraulic conductivity throughout the model domain.

The results of this analysis depend on assumptions about the hydrologic and geologic characteristics, as well as the locations of proposed pumping wells and water-demand scenarios associated with potential development. As solar facilities are planned, constructed, and begin operations, it is expected that new wells will be constructed and new data will be collected to refine the hydrologic and geologic assumptions used to build the Riverside East SEZ Model. Any new information incorporated into the model will change the results presented here. In addition, assumptions regarding the development of solar facilities should be revisited when improvements to the Riverside East SEZ Model are made, to provide a more accurate estimate of potential impacts on the basins.

The simulations performed for the high-, medium-, and low-water-demand scenarios that assume full build-out of the SEZ yielded results comparable to those from the more simplistic analyses used in the Solar PEIS (BLM and DOE 2012). Groundwater pumping has the potential to cause significant drawdown of groundwater elevations, but this effect would vary across the Riverside East SEZ, which was not represented in the Solar PEIS analyses. The aquifer characteristics in the region just to the south of Palen Lake (to the extent they are currently understood) lead to a significant cone of depression in groundwater elevations in the high- and medium-water-demand scenarios. Our preliminary modeling simulations suggest that groundwater drawdown would not affect the Colorado River Accounting Surface but could affect phreatic vegetative communities and sand dunes that are near Palen Lake. Further characterization of the hydrogeologic characteristics of this region is needed to improve the predictive capabilities of the Riverside East SEZ Model.

\subsection{Implications for Future Model Development}

Improvements to this assessment-level model could be made by incorporating new data regarding the hydrogeological framework and aquifer parameter values. The model's hydrostratigraphy could be changed. It is recommended that future models incorporate multiple layers to account for the lateral and vertical changes in hydraulic conductivity and aquifer behavior. Potential changes would be to include the (1) semi-confining units above the Bouse Formation in the northern portion of the Palo Verde Mesa and northwest of Desert Center and (2) confining low-permeability deposits in the eastern Chuckwalla Valley near Ford Dry Lake and the Genesis solar facility. Further, the inclusion of underlying confining layers would be accompanied by the need for a sensitivity analysis of the storage coefficient on the predicted groundwater drawdown related to solar operations. Drilling data could be used to support local discretization of multiple model layers. Also, the basal elevation surface could be adjusted in light of new information. Zonal and vertical changes could be made in the assignment of parameter values for alluvial materials. Some of this information could be obtained through SEZ site characterization during facility planning and development stages and through the logging of SEZ groundwater extraction wells or aquifer testing. The alluvium in the study area is highly spatially variable. Site-specific data would improve the design and accuracy of the model for assessing drawdown impacts. 


\section{Midland and Palo Verde Mesa Considerations}

The majority of the residual calibration error in the Phase 2 model was due to the head difference at the Midland well. While no inflows have been documented in the northern portion of the Palo Verde Mesa groundwater basin, CDWR (1979) listed subsurface inflow as a possible source of recharge. The simulated head of $255 \mathrm{ft}(77.7 \mathrm{~m})$ at the Midland well observation point at the northern valley edge in the Palo Verde Mesa groundwater basin is $72 \mathrm{ft}(22 \mathrm{~m})$ below the observed head of $327 \mathrm{ft}(99.7 \mathrm{~m})$ in 2010 . Without an influx of water upgradient (north) of Midland, the only substantial source of water to this well to be considered (outside of precipitation/mountain-front recharge) is from the Colorado River. However, the river stage is at a maximum elevation of only $283 \mathrm{ft}(86.4 \mathrm{~m})$, which is far below the observed head of $327 \mathrm{ft}$ $(99.7 \mathrm{~m})$. It is possible that there is a small influx of groundwater from the Rice Valley to the north, across a low point in the gap between the Little Maria and the Big Maria mountain ranges or through fractures or carbonates in the basement rocks. Groundwater near Midland could also be "mounded" north of an unmapped low-flow fault that creates a hydraulic separation from the remainder of the Palo Verde Mesa groundwater basin.

According to the USGS NWIS database, the ground surface elevation at the Midland well is only $10 \mathrm{ft}(3 \mathrm{~m})$ lower than the ground surface elevation at wells immediately on the north side of the "divide" in the basin to the north (Figure 12; USGS 2012). However, the groundwater elevation at the Midland well (approximately $330 \mathrm{ft}[100 \mathrm{~m}]$ above mean sea level) is $270 \mathrm{ft}(82 \mathrm{~m})$ lower than the greatest groundwater elevations in wells on the north side of the divide in the Rice Valley. This is similar to the elevation drop of more than $330 \mathrm{ft}(100 \mathrm{~m})$ from the documented Pinto Valley inflow location into the western Chuckwalla Valley, which involves alluvial inflow, groundwater "mounding" behind a fault zone, and possible interaction with basement carbonates in the area (USGS 2007, 2012). A similar groundwater inflow could exist from the Rice Valley at Midland. However, whether the depths/screen elevations of the Rice Valley wells are comparable to that of the Midland well is not known. The potential influx could be comparable to flows into the Chuckwalla Valley from the Pinto Valley and would significantly change (lower) the PEST-derived hydraulic conductivity in this area of the Palo Verde Mesa. This, in turn, could significantly increase the effect of solar facility pumping on groundwater and ephemeral surface water in the upper reaches of the northern Palo Verde Mesa, as well as on the Colorado River Accounting Surface.

\subsection{Summary of Riverside East SEZ Model Files and Future Use}

Modeling was performed by using GMS Version 8.3.4.16592 (64-bit) with a build date of August 24, 2012. The files are packaged in a single zip file. When unzipped, they may be useable by older or newer versions of GMS or by other commercial graphical user interfaces; however, their functionality cannot be guaranteed.

Within GMS, the project explorer includes MODFLOW-related items under the threedimensional grid data. The solution file sets include:

- RiversideEast_1L_1107.gpr is the Phase 1, pre-1942, steady-state model. 


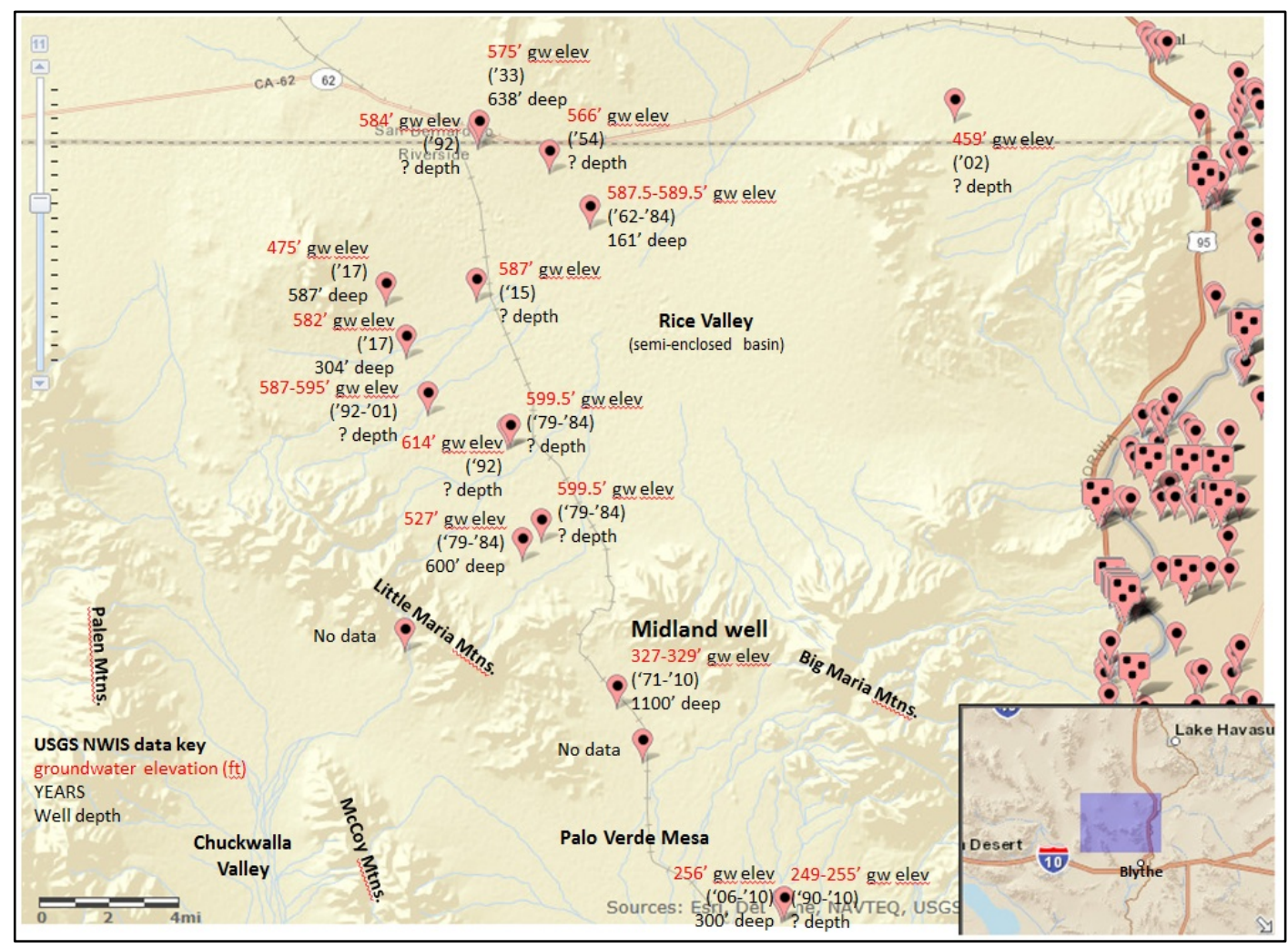

Figure 12 USGS NWIS Data for the Midland Well and Surrounding Wells in the Palo Verde Mesa and Rice Valley Groundwater Basins

- RiversideEast_1L_transONLY_1211_PilotPts.gpr is the Phase 2 transient model calibrated with parameter estimation for hydraulic conductivity, including baseline (i.e., agricultural, mining, and municipal) pumping for 69 years.

- RiversideEast_1L_transFWD_0107high.gpr is the Phase 3 model incorporating the effect of SEZ pumping. It uses the final heads from the calibrated transient model as starting heads and simulates a 20 -year period of continued baseline pumping and maximum SEZ pumping.

- RiversideEast_1L_transFWD_0107_baseline.gpr is the same as RiversideEast_1L_transFWD_0107high.gpr except that only baseline pumping is simulated (i.e., no SEZ-related pumping).

- “High DDN data set_0107"is a data set created using the GMS Data Set Calculator tool to determine the difference in drawdown between the 0107 high results at the 20 -year mark (with maximum SEZ pumping) and 0107_baseline results at the 20-year mark (without SEZ pumping). 


\section{Disclaimer on the Use of the Riverside East SEZ Model}

The numerical groundwater modeling studies were performed to analyze the potential impacts of groundwater pumping associated with utility-scale solar energy development. The models used for these analyses have relied on established hydrogeologic principles and established groundwater modeling software. The approaches taken have ranged from the development of new models based on existing data sources to the evaluation and modification of models already created by various agencies. While efforts were made to develop modeling tools for proper assessment of impacts from groundwater pumping to support solar energy, the models are not intended to be exact predictors of groundwater impacts that could be present over time in the study areas. Hydrogeologic information that is obtained as individual solar projects are developed should be used to refine, modify, and update the models and analyses used for this study. The reports associated with each groundwater modeling study make recommendations for the further development of the groundwater models as information becomes available.

MODFLOW-based modeling was performed using particular versions of Groundwater Modeling System (GMS), as described below. The model files associated with the groundwater modeling studies may be useable by older or newer versions of GMS or by other commercial graphical user interfaces; however, functionality cannot be guaranteed. 


\section{REFERENCES}

ADWR (Arizona Department of Water Resources), 2010, Ranegras Basin Plain, http://www.azwater.gov/azdwr/StatewidePlanning/RuralPrograms/OutsideAMAs_PDFs_for_ web/Lower_Colorado_River_Planning_Area/Ranegras_Plain_Basin.pdf.

AECOM, 2010a, "Numerical Groundwater Model: Evaluation of Proposed Project Groundwater Pumping, Desert Sunlight Solar Farm Chuckwalla Valley, Riverside, Calif.," prepared by AECOM, Camarillo, Calif., for Desert Sunlight Holdings LLC, Riverside, Calif.; appearing on pp. G-168 through G-192 of Appendix G in Desert Sunlight Solar Farm Project California Desert Conservation Area Plan Amendment and Final Environmental Impact Statement, DOI Control No. FES 10-39, NEPA Tracking No. 001-BLM-CA-060-0009-0033-EIS, CACA \#48649, prepared by Bureau of Land Management for Palm Springs-South Coast Field Office, Palm Springs, Calif., April 2011.

AECOM, 2010b, "Data Response in Technical Area: Soil and Water Resources (AFC Sections 5.12 and 5.17) Response Date: Jan. 6," Appendix J.3, "Hydrogeologic Investigation Report," Application for Certification, Blythe Solar Power Project, Riverside, California, http://www.energy.ca.gov/sitingcases/genesis_solar/documents/exhibits-406-402/Genesis_StaffExhibit_16.pdf.

BLM (Bureau of Land Management), 2010a, Plan Amendment/Final EIS for the Blythe Solar Power Project, DOI Control No. FES 10-41, NEPA Tracking No. DOI-BLM-CA-060-00100013-EIS, prepared for Palm Springs-South Coast Field Office, Palm Springs, Calif., Aug.

BLM, 2010b, Plan Amendment/Final EIS for the Genesis Solar Power Project, DOI Control No. FES 10-42, NEPA Tracking No. DOI-BLM-CA-060-0010-0015-EIS, prepared for Palm Springs - South Coast Field Office, Palm Springs, Calif., Aug.

BLM, 2012, Approved Resource Management Plan Amendments/Record of Decision (ROD) for Solar Energy Development in Six Southwestern States, Oct.

BLM and DOE (U.S. Department of Energy), 2010, Draft Environmental Impact Statement for Solar Energy Development in Six Southwestern States, DES 10-59, DOE/EIS-0403, prepared by Argonne National Laboratory, Argonne, Ill., Dec.

BLM and DOE, 2012, Final Environmental Impact Statement for Solar Energy Development in Six Southwestern States, FES 12-24, DOE/EIS-0403, prepared by Argonne National Laboratory, Argonne, Ill., July.

Buising, A.V., 1990, "The Bouse Formation and Bracketing Units, Southeastern California and Western Arizona: Implications for the Evolution of the Proto-Gulf of California and the Lower Colorado River," Journal of Geophysical Research 95(B12):20, 111-120, 132, Nov. 10.

CDWR (California Department of Water Resources), 1975, California's Ground Water, Bulletin $118-75$. 
CDWR, 1979, Sources of Power Plant Cooling Water in the Desert Area of Southern California - Reconnaissance Study, Bulletin 91-24, prepared by U.S. Department of the Interior, U.S. Geological Survey, Aug.

CDWR, 2003, California's Groundwater, Bulletin 118, Update 2003, http://www.water.ca.gov/ groundwater/bulletin118/update2003.cfm.

CDWR, 2005, "Colorado River Hydrologic Region - Chuckwalla Planning Area (PA 1003) Water Use and Distribution of Dedicated Supplies," Colorado River Region Planning Area Reports, PA-1003, http://www.waterplan.water.ca.gov/planningareas/cr/index.cfm.

Driscoll, F., 1986, Groundwater and Wells, Johnson Filtration Systems, Inc., St. Paul, Minn. GEI Consultants, Inc., 2010, Eagle Mountain Pumped Storage Project, Draft Environmental Impact Report, Volume III, Technical Memorandum, Appendix C, prepared by GEI Consultants, Inc., Rancho Cordova, Calif., for State Water Resources Control Board, Sacramento, Calif., July.

Gesch, D.B., 2007, “The National Elevation Dataset,” pp. 99-118 in D. Maune (editor), Digital Elevation Model Technologies and Applications: The DEM User's Manual, 2nd Edition, American Society for Photogrammetry and Remote Sensing, Bethesda, Md.

Gesch, D., et al., 2002, “The National Elevation Dataset," Photogrammetric Engineering and Remote Sensing 68(1):5-11.

Godfrey, P., et al., 2012, "Groundwater and Large-Scale Renewable Energy Projects on Federal Land: Chuckwalla Valley Groundwater Basin," in Proceedings of the 2012 Arizona Hydrological Society Annual Water Symposium, Phoenix, Ariz., Sept. 18-21.

Greer, C, et al., 2013, "Using MODFLOW and PEST To Evaluate the Impact of Proposed Solar Energy Facilities on BLM Lands in the Southern California Desert," pp. 707-713 in Modflow and More 2013: Translating Science into Practice - Conference Proceedings, Golden, Colo., June $2-5$.

Leake, S.A., et al., 2008, Use of Superposition Models to Simulate Possible Depletion of Colorado River Water by Ground-Water Withdrawal, Scientific Investigations Report 20085189, U.S. Department of the Interior, U.S. Geological Survey.

Mariano, J., et al., 1986, Bouguer and Isostatic Residual Gravity Maps of the Colorado River Region Including the Kingman, Needles, Salton Sea and El Centro Quadrangles, Open-File Report 86-347, U.S. Department of the Interior U.S. Geological Survey.

Metzger D.G., et al., 1973, Geohydrology of the Parker-Blythe-Cibola Area, Arizona and California, Professional Paper 486-G, U.S. Geological Survey, Washington, D.C.

Quinn, J.J., et al., 2013, Groundwater Model to Assess Water Resource Impacts at the Brenda Solar Energy Zone, ANL/EVS/R-13/9, Argonne National Laboratory, Argonne, Ill. 
Weile, S.M., et al., 2008, Update of the Accounting Surface along the Lower Colorado River, Scientific Investigations Report 2008-5113, U.S Department of the Interior, U.S. Geological Survey, Reston, Va.

West Yost Associates, 2011, Revised Groundwater Baseline Data Report, prepared by West Yost Associates, Davis, Calif., for First Solar Electric LLC (Desert Sunlight solar facility), Davis, Calif.

Wilson, R.P., and S.J. Owen-Joyce, 1994, Method To Identify Wells That Yield Water That Will Be Replaced by Colorado River Water in Arizona, California, Nevada, and Utah, WaterResources Investigations Report 94-4005, U.S. Geological Survey, Tucson, Ariz.

WorleyParsons, 2009, Genesis Solar Energy Project Groundwater Resources Investigation, TN-55916, Folsom, Calif., Jan. 8.

USGS (U.S. Geological Survey), 2007, Hydrologic and Geologic Reconnaissance of Pinto Basin, Joshua Tree National Monument, Riverside County, California, Water-Supply Paper 1475-O, http:/www.nps.gov/history/history/online_books/geology/publications/wsp/ 1475-O/contents.htm. Accessed Nov. 5, 2012.

USGS, 2012, National Water Information System (Water Data for the Nation), http://waterdata. usgs.gov/nwis. Accessed Aug. 17, 2012. 



\section{Argonne}

\section{Environmental Science Division}

Argonne National Laboratory

9700 South Cass Avenue, Bldg. 240

Argonne, IL 60439-4847

www.anl.gov

www.evs.anl.gov 